REVIEW

\title{
Carpe noctem: the importance of bats as bioindicators
}

\author{
Gareth Jones $^{1, *}{ }^{\text {, David S. Jacobs }}{ }^{2}$, Thomas H. Kunz ${ }^{3}$, Michael R. Willig ${ }^{4}$, Paul A. Racey ${ }^{5}$ \\ ${ }^{1}$ School of Biological Sciences, University of Bristol, Woodland Road, Bristol BS8 1UG, UK \\ ${ }^{2}$ Zoology Department, University of Cape Town, Rondesbosch 7701, Cape Town, South Africa \\ ${ }^{3}$ Center for Ecology and Conservation Biology, Department of Biology, Boston University, Boston, Massachusetts 02215, USA \\ ${ }^{4}$ Center for Environmental Sciences and Engineering and Department of Ecology and Evolutionary Biology, \\ University of Connecticut, Storrs, Connecticut 06269-4210, USA \\ ${ }^{5}$ School of Biological Sciences, University of Aberdeen, Tillydrone Avenue, Aberdeen AB24 2TN, UK
}

\begin{abstract}
The earth is now subject to climate change and habitat deterioration on unprecedented scales. Monitoring climate change and habitat loss alone is insufficient if we are to understand the effects of these factors on complex biological communities. It is therefore important to identify bioindicator taxa that show measurable responses to climate change and habitat loss and that reflect wider-scale impacts on the biota of interest. We argue that bats have enormous potential as bioindicators: they show taxonomic stability, trends in their populations can be monitored, short- and longterm effects on populations can be measured and they are distributed widely around the globe. Because insectivorous bats occupy high trophic levels, they are sensitive to accumulations of pesticides and other toxins, and changes in their abundance may reflect changes in populations of arthropod prey species. Bats provide several ecosystem services, and hence reflect the status of the plant populations on which they feed and pollinate as well as the productivity of insect communities. Bat populations are affected by a wide range of stressors that affect many other taxa. In particular, changes in bat numbers or activity can be related to climate change (including extremes of drought, heat, cold and precipitation, cyclones and sea level rise), deterioration of water quality, agricultural intensification, loss and fragmentation of forests, fatalities at wind turbines, disease, pesticide use and overhunting. There is an urgent need to implement a global network for monitoring bat populations so their role as bioindicators can be used to its full potential.
\end{abstract}

KEY WORDS: Chiroptera · Indicator species · Environmental stressors

Resale or republication not permitted without written consent of the publisher

\section{INTRODUCTION}

On a global scale, the structure and functionality of ecosystems are changing at an unprecedented rate (NRC 2001, 2003, Soares-Filho et al. 2006), primarily as a consequence of human activities associated with the provisioning of food and fibre, or the emission of greenhouse gases and use of carbon-based resources for energy production (Vitousek et al. 1997, Tilman et al. 2001, Hooper et al. 2005). Indeed, as human populations continue to expand in size and become increasingly urban in nature, such environmental problems promise to become even more exacerbated (Pimm et al. 1995, Thomas et al. 2004, Soares-Filho et al. 2006, Kareiva et al. 2007). At the same time, the magnitude of change around the globe is quite variable, as is the nature of the human activities that alter and fragment landscapes (Sala et al. 2000).

From the perspective of biota, 2 distinctly different kinds of global change are critical to understand and monitor. The first involves alteration of conditions associated with global climate change (Hughes 2000, Walther et al. 2002, Parmesan \& Yohe 2003, Rosenzweig et al. 2007). This manifests as altered regional patterns of precipitation and temperature, including disturbance regimes (e.g. frequency and intensity of 
tropical storms or drought). The second involves conversion of natural habitats to those managed to directly or indirectly support humans, such as forestry, agriculture, industry and urbanization (Vitousek et al. 1997, Foley et al. 2005). Conversion ultimately reduces the extent and increases the fragmentation of natural habitats (Turner et al. 2001, Fahrig 2003). Taken together, global climate change and habitat conversion may threaten the long-term persistence of many species of plants and animals, alter distributional patterns at global and regional levels and result in local assemblages of species that are quite different from those that currently constitute coevolved communities (Wilcox \& Murphy 1985, Chapin et al. 2000, McCarty 2001, Walther et al. 2002, Parmesan 2006).

Monitoring global climatic change and habitat conversion is not sufficient for understanding or managing the consequences of human activity on biological systems. Biological systems are geographically variable, inherently complex and comprise a multitude of interacting species. They likely respond in non-linear and scale-dependent fashions to aspects of global change, and may do so in idiosyncratic manners associated with the unique assemblages of species that they comprise (Levin 1992, Allen \& Hoekstra 1993, With \& Crist 1995). Thus, a broad-scale network of monitoring that captures local, regional and global components of the earth's biota is critical for understanding and forecasting responses to climate change and habitat conversion, as well as managing natural resources in a longterm, sustainable fashion.

In this paper we argue that bats are ideal indicators of human-induced climate change and habitat quality (Fig. 1). (1) We discuss features that define good bioindicator taxa. (2) We review characteristics of bats that make them ideally suited as bioindicators. (3) We present case studies where bats have been used successfully as bioindicators. We identify some of the major sources of environmental stress to which bats are subjected, and argue that some of the major stressors that have an impact on biodiversity in general also have major impacts on bat populations, emphasising their potential suitability as bioindicators. We conclude by identifying the need for implementation of largescale monitoring schemes using bats as bioindicators.

\section{INDICATOR TAXA FOR ECOLOGICAL MONITORING AND BATS AS BIOINDICATORS}

\section{Types of bioindicators}

It is important to recognise the distinction between biodiversity, ecological and environmental indicators. Biodiversity indicators capture responses of a range of taxa and reflect components of biological diversity such as species richness and species diversity. Ecological indicators consist of taxa or assemblages that are sensitive to identified environmental stress factors that demonstrate the effect of those stress factors on biota, and whose responses reflect responses of at least a subset of other taxa present in the habitat. Environmental indicators respond in predictable ways to specific environmental disturbances (McGeoch 1998). Ideal biodiversity indicators may not exist because taxa often respond to environmental stressors in different ways. Nevertheless, indicators that represent responses over a range of trophic levels (e.g. insectivores and insect prey, pollinators and pollinated plants) can represent the effects of environmental degradation on specific ecological processes, and bats can thus have important roles as ecological indicators. Bats can also be important environmental indicators because they are sensitive to a wide range of environmental stresses to which they respond in predictable ways (Fig. 1). Additionally, the wide range of food sources exploited by bats allows them to be used as indicators for a wide range of environmental stressors.

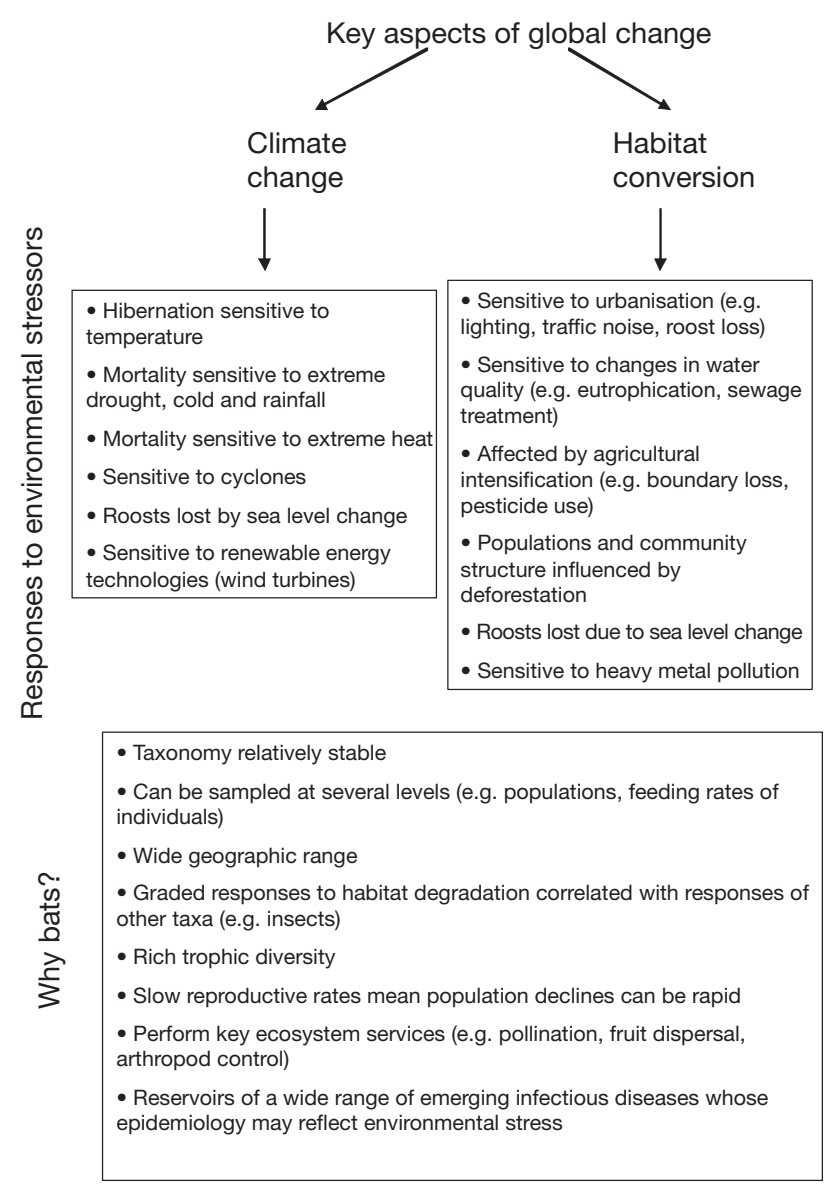

Fig. 1. Schematic outline of reasons for bats' excellent potential as bioindicators 
Monitoring natural populations can have a variety of goals and the decision on which group of species to use as indicators must be influenced by the goals of the monitoring programme (McGeoch 1998, Caro \& O'Doherty 1999, Moreno et al. 2007). Monitoring ecosystem health, for example, to identify the nature or source of pollution would require a different set of indicator species (environmental indicators) to those for monitoring the effects of habitat loss on patterns of species richness (biodiversity indicators) or on ecological processes (ecological indicators) (McGeoch 1998). Thus, before a monitoring programme begins and indicator species are selected, the goals and scale of the programme must be clearly formulated (McGeoch 1998, Caro \& O'Doherty 1999, Moreno et al. 2007).

Biodiversity indicator species have characteristics that can be used as an index of attributes (e.g. presence/absence, population density and relative abundance) of other species comprising the biota of interest (Landres et al. 1988). Biodiversity indicator taxa are thus surrogates for an entire biota in which species richness or the lack of human resources (e.g. time, money and trained personnel) preclude monitoring the fate of all taxa (Moreno et al. 2007) as a means of monitoring human-induced environmental degradation. If indicator taxa are to be suitable surrogates for a diverse array of taxa, they should possess a suite of characteristics that are rarely found in any single species (Spector \& Forsyth 1998). Thus, a small number of indicator species are often used as surrogates (Caro \& O'Doherty 1999). These species collectively must have characteristics that make them easy to identify (stable taxonomy), be easy to sample, be widely distributed geographically, show graded responses to habitat degradation and these responses should be correlated with the responses of other taxa (Spector \& Forsyth 1998, Moreno et al. 2007). They also represent the biota of interest as well as the variety of functional groups comprising it. Their natural history should be well-known so that the broader implications of changes in their abundance, and the significance of their correlations with other taxa or environmental variables, could be used to evaluate the status of the entire community (Moreno et al. 2007).

\section{Characteristics of bioindicator taxa}

Indicator species should have sufficient taxonomic stability (low rate of species invalidation through synonymy) to permit their accurate and consistent identification (Pearson \& Cassola 1992). The tools and personnel associated with such identification (e.g. identification keys and taxonomists) must be reliable and readily available. It is essential that a significant portion of the population of an indicator species can be sampled quickly and, with reasonable effort, on a regular basis. Such sampling must yield relative or absolute abundance data so that a profile of the species assemblages can be compared (Spector \& Forsyth 1998); presence/absence data will not provide information on the shifts in relative abundance necessary for monitoring environmental change (Spector \& Forsyth 1998). It is also important that assemblage composition can be easily characterized in terms of species as well as guilds or ensembles (e.g. those associated with foraging, dietary habits or roosting) to isolate the ecological factors causing shifts in relative abundance.

Environmental degradation can occur over a variety of scales (e.g. changes in land use such as agricultural intensification) resulting in very localized or widespread impacts. Species with highly restricted ranges may be adequate to monitor such changes and would allow the location of the source of pollution or disturbance with greater accuracy (Caro \& O'Doherty 1999). However, due to the globalization of human economic activity, threats to biodiversity are increasingly acting on a global scale. Monitoring the impacts of such threats through indicator species requires that the chosen species have broad geographic ranges (Spector \& Forsyth 1998). Bats, as volant taxa, fulfill this criterion better than most other taxa.

As urbanization expands into previously unoccupied landscapes, habitat loss or degradation and its monitoring become increasingly important. Indicator species should thus be sensitive to habitat loss or degradation but should show a graded response over long time-periods (Spector \& Forsyth 1998). Such indicator species allow the detection of disturbance while providing an opportunity to redress its cause. A graded response would also provide insight into the severity of the disturbance. Taxa that are too sensitive and become locally extinct over a short time are unsuitable because they would not allow the detection of changes in relative abundance and, at best, monitoring would only reveal presence at some time and absence at another. Indicator taxa that are too insensitive to habitat degradation, on the other hand, would show no change, even as sensitive species go extinct or their habitats become severely degraded.

Related to a sensitive and graded response is the correlation of the response of the indicator species with responses by other species (Spector \& Forsyth 1998, Moreno et al. 2007). Such a response is essential for biodiversity indicator taxa, but not for environmental indicators. Response correlations may be positive or negative, but correct interpretation is dependent on knowledge of the natural history of the species involved (Moreno et al. 2007). 


\section{Taxa used as bioindicators}

Invertebrates are most commonly used as indicators (McGeoch 2007, Moreno et al. 2007). Insects are favoured as indicator taxa because they comprise a large proportion of terrestrial species richness, are often habitat specialists, are sensitive to small-scale heterogeneity (Hill 1996, Niemela et al. 1996) and play a significant role in ecosystem functions (McGeoch 2007). However, the use of insects as indicator species is not always straightforward because many species remain undescribed or are in need of taxonomic revision (Spector \& Forsyth 1998). Moreover, insects can be difficult to sample quickly and efficiently. Instead, entomologists have advocated the use of subsets of certain insect taxa, such as dung beetles, based on ease of sampling and response to habitat gradients (Spector \& Forsyth 1998, McGeoch et al. 2002).

Birds are useful biological indicators (Gregory et al. 2005), especially at the edges of urban areas, because they are ecologically versatile and can be monitored relatively easily and cheaply (Koskimies 1989). They are also highly mobile and therefore can respond rapidly to changes in their habitat (Fuller et al. 1995a, Louette et al. 1995). It is at the edges of urban areas, where habitat structure is often highly fragmented, that relationships between humans and bird assemblages are easiest to study (Cody 1985). Thus, birds have long been used as both environmental (e.g. Kushlan 1993, Alleva et al. 2006) and biodiversity indicators (e.g. Reynaud \& Thioulouse 2000).

\section{Why bats?}

Bats are excellent indicator taxa and thus have been used as ecological indicators of habitat quality (Wickramasinghe et al. 2003, Kalcounis-Rueppell et al. 2007). Bats are also sensitive to human-induced changes to ecosystems (Fenton et al. 1992, Estrada et al. 1993, Medellín et al. 2000, Moreno \& Halffter 2000, 2001, Estrada \& Coates-Estrada 2001a, b, Clarke et al. 2005a,b, Hayes \& Loeb 2007, Kunz et al. 2007). However, in neotropical coffee plantations bats showed modification in their guild (or ensemble) structure, but the species composition did not change with the alteration of habitat from undisturbed cloud forest to coffee plantations. Species composition of both frogs and dung beetles changed across the same habitat gradients (Pineda et al. 2005). Similarly, although bat activity was significantly different between organic and conventional farms in southern England and Wales, species composition was not (Wickramasinghe et al. 2003). Thus, caution is necessary when selecting groups of species as indicators and sampling should be conducted at the appropriate level (i.e. species versus ensemble) and with appropriate units (i.e. activity versus species richness).

Insectivorous bats occupy higher trophic levels and would be excellent indicators owing to the relationship between contaminant and/or environmental disturbance and trophic levels (Alleva et al. 2006). Dietary accumulation and metabolic capacity increases at higher positions in the food chain, and insectivorous bats are likely to show the consequences of pollutants before organisms at lower trophic levels such as herbivorous insects or birds. The slow reproductive rates of bats mean that populations take a long time to recover from declines, and although population declines take longer to detect, trends are less subject to noise that may confound patterns in short-term studies of fast reproducing taxa such as insects. Although bat populations can be monitored directly to assess longterm population changes (Walsh et al. 2001), shortterm impacts on insectivorous bats can be quantified by monitoring 'feeding buzzes' - increases in the rate of emission of echolocation calls as bats home in on insect prey (Griffin et al. 1960).

With respect to other criteria that make groups of species suitable indicators, the taxonomy of bats is mostly stable, at least at the species level. Although the genera of some bat species have been changed (Kearney et al. 2002, Simmons 2005), relatively few species names have been altered. However, several new cryptic species have recently been discovered (Jones \& Van Parijs 1993, Kingston et al. 2001, Mayer \& von Helversen 2001, Kiefer et al. 2002, Kingston \& Rossiter 2004, Jacobs et al. 2006) and there are likely to be more as bat research increases. However, this problem is relatively minor (compared to insects or birds with their greater diversity) and is easily circumvented by the careful choice of indicator species.

Unfortunately, few studies have tested the suitability of bats as indicator species with respect to the other criteria (e.g. correlation of bat responses to habitat disturbance with those of other species). Thus it is important to appreciate that although bats may have great potential as indicator species, other indicator taxa that exploit ecosystem services in complimentary ways should also be incorporated in monitoring programmes (e.g. Pocock \& Jennings 2008). Similarly, a variety of methods have to be used to sample bats efficiently and completely (Flaquer et al. 2007, MacSwiney et al. 2008) and sampling methods involving capture can be labour-intensive and time-consuming (Hayes et al. 2009, Kunz et al. 2009a). Cost-effectiveness can be an important criterion in determining the practical feasibility of long-term surveys of potential indicator taxa (Gardner et al. 2008). Although bat surveys can involve high capital costs and intensive training, advances in 
acoustic technology mean that acoustic monitoring of insectivorous bat assemblages should become increasingly efficient and affordable (Parsons \& Szewczak 2009). Moreover, methods for surveying many species, including frugivorous and nectar-feeding taxa, involve low-cost trapping methods such as the use of mist-nets and harp traps (Kunz et al. 2009b).

\section{Measuring bioindicator sensitivity}

Attention should also be paid to how best to assess sensitivity. Sensitivity is often measured by quantifying differences in abundance or density, for example in disturbed versus non-disturbed habitats. However, abundance may not always be a suitable measure of sensitivity. If competition occurs for the best quality habitats (e.g. those that generate highest foraging returns) and they are limited in availability, a small number of highly competitive individuals may exist in the best habitats, with large numbers of subdominants relegated to lower quality areas (van Horne 1983). For example, the presence of large numbers of male bats at high elevation sites supports the hypothesis that the best quality lowland sites are monopolised by breeding females and perhaps by high-quality males (Barclay 1991, Russo 2002, Senior et al. 2005, Cryan \& Veilleux 2007, Cryan \& Diehl 2009).

Any study of bioindicators should assess whether abundance or density is a valid indicator of sensitivity (Hayes et al. 2009, Kunz et al. 2009a). Competitive effects may occur between as well as within species. For example, in forest fragments in French Guiana, the smaller Artibeus obscurus appears to be relegated to fragmented habitats by $A$. jamaicensis, which excludes A. obscurus from continuous forest (Henry et al. 2007). The sex ratio of $A$. obscurus is significantly malebiased in fragments, and haematocrits (a proxy of physiological condition) were significantly lower in fragments compared with continuous forest. Thus sex ratios and physiological measures may be better indicators of sensitivity to habitat disruption than measures of abundance or densities in some circumstances.

\section{THE IMPORTANCE OF BATS IN ECOSYSTEMS}

The extensive taxonomic and functional diversity of bats makes them well suited as bioindicators (Patterson et al. 2003, Simmons \& Conway 2003). Indeed, bats are among the most diverse and geographically dispersed group of living mammals. They form some of the largest non-human aggregations of mammals, and may be among the most abundant groups of mammals when measured in numbers of individuals (Kunz 2003,
O'Shea \& Bogan 2003); only members of the order Rodentia exceed bats in number of species, and over 1116 species of bats have been described (Simmons 2005). Powered flight sets bats apart from other mammals, and this most likely has been an important factor contributing to their widespread distribution and diversity (Kunz \& Fenton 2003). Living bats are known from all continents except Antarctica and their distribution ranges from the southern tip of South America to northern Scandinavia (Kunz \& Pierson 1994, Willig et al. 2003). They are absent only from polar regions and some isolated oceanic islands. Powered flight has also contributed to their extraordinary feeding and roosting habits, reproductive strategies and social behaviours (Patterson et al. 2003, Simmons \& Conway 2003). Roosting habitats include foliage, caves, rock crevices, hollow trees, crevices beneath exfoliating bark and an assortment of man-made structures (Kunz 1982, Kunz \& Lumsden 2003, Kunz \& Reynolds 2003). Their rich dietary diversity, which includes insects, fruits, leaves, flowers, nectar, pollen, seeds, fish, frogs, other vertebrates and blood, is unparalleled among the orders of living mammals (Kunz \& Pierson 1994, Patterson et al. 2003, Simmons \& Conway 2003).

Bats are important in terms of their ecological and economic roles. Because bats fill such a wide array of ecological niches, they offer an important multisensory role in assessing ecosystem health. Old World pteropodids and New World phyllostomids are important pollinators and seed dispersers for a number of ecologically and economically important plants (Fujita \& Tuttle 1991, Kunz \& Pierson 1994, Kunz 1996, Hodgkison et al. 2003). The New World plant-visiting bat Leptonycteris curasoae appears to be the major pollinator of 2 primary cactus species of the Sonoran Desert, the cardon and organ pipe cactuses (Fleming \& Valiente-Banuet 2002, Molina-Freaner et al. 2004). The Old World bats Rousettus aegypticaus, Epomophorus wahlbergi and Eidolon helvum pollinate flowers of the baobab tree, an economically important species in the African savannah (Kunz 1996). On faunally depauperate oceanic islands, pteropodids are often the sole pollinators of plants that are known to have multiple pollinators on mainland areas, and they are often the only vertebrates large enough to carry large-seeded fruits (Fleming \& Racey 2009). Thus, in these assemblages, plant-visiting bats may fulfill keystone roles in structuring local forest communities. As frequent dispersers of pioneer species such as Solanum and Piper, bats are important for the revegetation of cleared areas (Kelm et al. 2008). Over 186 paleotropical plant species utilized by flying foxes (Pteropus) have been identified as being of economic importance to people for a variety of products, including food, medicines, dyes, fibers, ornamental plants, and timber (Fujita \& Tuttle 1991). For example, pteropodids are the primary 
pollinators of 2 plant species that are extremely important to the local economies of Southeast Asia, durian Durio zibethinus and petai Parkia speciosa and P. javanica, and thus play vital roles in both pollination and seed dispersal of a number of valuable timber species (Start \& Marshall 1976).

Insectivorous species are the primary consumers of nocturnal insects. Given the relatively large volumes consumed (up to $100 \%$ of body mass per night, e.g. Kurta et al. 1989) and the long distances travelled (several $\mathrm{km}$ per night), these bats are thought to play a major role in suppressing nocturnal insect populations and transporting nutrients across the landscape, particularly from stream corridors to tree roosts (Pierson 1998). Indeed, experiments show that bat exclusion reduces the numbers of arthropods and hence limits herbivory more than bird exclusion in neotropical forests (Kalka et al. 2008). Similar exclusions also show that bats significantly reduce arthropod numbers in coffee plantations, especially during the wet season (Williams-Guillén et al. 2008). Although mosquitoes are often touted as an important dietary item of some insectivorous bats, the overwhelming numbers and diversity of insects eaten by bats are represented by other groups, namely lepidopterans, coleopterans, homopterans, hemipterans and trichopterans (Anthony \& Kunz 1977, Whitaker 1993, 1995, Agosta 2002, Agosta \& Morton 2003). Bats are predators on a number of economically important insects, including cucumber beetles, June bugs, corn earworm moths, cotton bollworm moths, tobacco budworm moths and Jerusalem crickets (Whitaker 1995, Lee \& McCracken 2005), which are important agricultural pests on such crops as corn, cotton and potatoes (Whitaker 1993, Cleveland et al. 2006). Extrapolations based on data from the Winter Garden region of south-central Texas suggest that the presence of large numbers of Brazilian free-tailed bats Tadarida brasiliensis can reduce the influence of insect herbivory from cotton boll worms and corn earworms on a transcontinental scale. With a few exceptions, the model suggests that both genetically engineered (Bt) and conventional cotton production is more profitable when large numbers of insectivorous bats are present (Cleveland et al. 2006, Federico et al. 2008).

\section{BAT POPULATIONS UNDER THREAT}

Bat populations can be readily monitored over long time periods, as shown for example by the UK's National Bat Monitoring Programme (NBMP) implemented by the Bat Conservation Trust. This programme has been operating since 1995 and uses a combination of standardized counting methods - including roost counts, hibernation counts and bat detector surveys - to assess the relative abundance of a number of bat species in the UK (Walsh et al. 2001). The NBMP has shown that trends in bat populations can be statistically identified from data collected through standardized monitoring schemes.

Bat populations appear to be declining almost everywhere in the world, presumably in response to a series of environmental stresses, many of which are induced by humans. Several species have apparently become extinct, including the pteropodids Pteropus brunneus from Australia, P. pilosus from Palau, P. subniger from the Mascarene Islands, $P$. tokudae from Guam, Mystacina robusta from New Zealand and Nyctophilus howensis from Lord Howe Island (Kunz \& Pierson 1994). For many other species, ranges are contracting, numbers are declining and only remnant populations remain. Species in decline probably include the pteropodids Aproteles bulmerae in Papua New Guinea, P. mariannus in Guam and Emballonura semicaudata on several Pacific islands, Eumops glaucinus in the USA, Rhinolophus hipposideros and Rhinolophus ferrumequinum in much of Europe (Kunz \& Pierson 1994). Coleura seychellensis now has a population estimated at only 100 ind. in the Seychelles (Bambini et al. 2006). Other species usually considered abundant have also experienced declines. For example, the numbers of Pipistrellus sp., the most common bats in Britain, decreased by $62 \%$ according to roost counts between 1978 and 1987 (Stebbings 1988).

Hence bats are taxonomically and functionally diverse, often abundant, global in distribution and provide key ecosystem services. Population declines suggest that bats are affected by environmental stressors, and that monitoring of their populations may give insight into the importance of these stressors in a more general context. We now review specific case studies that illustrate the potentially important roles that bats can play as bioindicators, emphasizing mechanisms that might drive population declines.

\section{ENVIRONMENTAL STRESSORS AFFECTING BAT POPULATIONS}

\section{Global climate change}

There is broad consensus that we are currently in a period of rapid and global climate change, and that the impact of these changes can already be observed in a range of ecosystems (e.g. Parmesan \& Yohe 2003). Not only are global temperatures increasing, some meteorological events are becoming more extreme, such as the number of days with exceptionally heavy precipitation in North America (Peterson et al. 2008). Global 
climate change is likely to have multiple impacts on bats. Newson et al. (2009) gave 3 examples of how monitoring bat populations could be used as effective indicators of the effects of climate change on migratory species. Monitoring bats in European hibernacula, populations of the straw-coloured fruit bat Eidolon helvum in Africa and Brazilian free-tailed bats Tadarida brasiliensis at maternity roosts in North America were considered to be valuable potential indicators of negative effects of climate change. Some specific effects of extreme climatic events are highlighted below.

\section{Incremental increases in temperature: physiological impacts}

The reproductive cycle of temperate zone bats is closely linked to their pattern of hibernation (Racey \& Entwistle 2000). Temperate species mate in autumn and winter and spermatozoa are stored in the female reproductive tract until spring. If bats experience warm conditions and a supply of food in the second half of winter, they will arouse from hibernation prematurely, ovulate and become pregnant. Experimentally, the timing of births can be altered by up to 3 mo by manipulating environmental conditions (Racey 1972). Conversely, if bats experience periods of inclement weather associated with food shortages during pregnancy, they will become torpid and the gestation period is extended (Racey 1973, Racey \& Swift 1981). The ability of bats to halt, speed up or slow down the rate of foetal growth is unique among mammals (Racey 1982). Given this extreme dependence on external temperatures and food supply, the timing of reproductive cycles of temperate bats is likely to be significantly affected by climate change. In greater horseshoe bats Rhinolophus ferrumequinum, birth timing was significantly correlated with spring temperature, with young being born earlier after warmer springs; births were approximately $18 \mathrm{~d}$ earlier when spring temperatures rose by $2^{\circ} \mathrm{C}$ (Ransome \& McOwat 1994). To date, however, the only documented example of extreme disruption of the timing of reproductive events has been the pregnancies and births reported for the mouse-eared bat Myotis myotis in December in the Doñana Reserve in southern Spain. These occurred 6 mo before the usual birth period for this pan-European species (Ibáñez 1997).

In captivity, spermatozoa stored in the female reproductive tract lose their viability if the bats are not provided with conditions suitable for hibernation (Racey 1972, Racey \& Entwistle 2000). If unsuitable hibernation conditions similarly affect bats in the wild, and males in particular (which also store spermatozoa in their epididymis), their reproductive success may be compromised.

The predicted decrease in frequency or even the disappearance of extreme cold winters may result in a reduced period of hibernation, increased winter activity and reduced reliance on the relatively stable temperatures of underground hibernation sites. An earlier spring would presumably also result in a shorter hibernation period and hence the earlier appearance of foraging bats. If sufficient food is available, an earlier emergence from hibernation may have no detrimental effect on population size. However, the occurrence of later periods of cold weather could inflict significant mortality. Over 2 decades ago, before climate change became a matter of concern, Avery (1985) showed that, over a 3 yr period, pipistrelles (Pipistrellus spp.) appeared over a fenland foraging site in every winter month and on a third of all winter nights. Many temperate bats species already feed regularly during the winter months, and are likely to adapt to warmer winters by increasing activity further. Such warmer weather may lead to increased availability of flying insects when the temperature rises above the threshold for insect flight (ca. $10^{\circ} \mathrm{C}$ ). Climate change is predicted to change energetic demands during hibernation and hence alter the distribution of hibernating species (Humphries et al. 2002). Large die-offs ( $\leq 75 \%$ at some hibernacula) of bats in the genus Myotis have been reported in caves and mines in the northeastern USA, termed white-nose syndrome because a white fungus is apparent in the muzzle of dead and moribund bats (Blehert et al. 2009) (Fig. 2). The fungus is phylogenetically related to Geomyces spp. and grows on the muzzles, ears and wing membranes of affected bats. No causal pathogen ultimately responsible for the die-offs has yet been identified; however, unusually warm and erratic winters may have affected the food supply or hibernal cycle of these bats and pesticides may also be involved in weakening their immune system (Locke 2008). Bats, in this case, may be viewed as a mammalian analogue to the canary in a coal mine, warning of impending ecological stress (canaries were used to detect gases such as carbon monoxide in coal mines in Britain until 1986 because of their sensitivity to odourless but lethal carbon monoxide gas).

Incremental increases in temperature: range shifts

Climate change may also cause changes in the distribution of bats both at local and global levels. La Val (2004) analysed capture data for bats in the Monteverde Cloud Forest in the Tilaran Mountains of Costa Rica over a 27 yr period. Although capture rates did not change significantly, at least 24 species previously 
associated with the lowlands were recorded at high elevations during this period. La Val (2004) attributed this shift in distribution to climate change as well as forest clearance and an increase in area of secondary forest.

Pipistrellus kuhlii, a bat species typically associated with Mediterranean regions of Europe, has undergone a substantial northward range shift over the past $15 \mathrm{yr}$. The species is now found in several countries in central and eastern Europe, and its northward range expansion may be the result of sustained recent increases in global temperature (Sachanowicz et al. 2006). Because bats are volant they can potentially shift ranges relatively rapidly, and so changes in their distribution may be valuable indicators of climate change.

\section{Extreme drought and cold: Miniopterus bassani}

In 2006, South Australia experienced the driest year on record, with the lowest rainfall since records began in 1869, at less than half the annual average, and no surface water in any of the wetlands. This presumably reduced the insect food supply available to the southern bent-winged bat Miniopterus bassani, the entire population of which depends on 2 maternity sites in the area. In addition, the minimum ambient temperature in October 2006 fell below $5^{\circ} \mathrm{C}$ on 18 occasions, and on 7 of these it fell below zero. In November, temperatures fell to $5^{\circ} \mathrm{C}$ or below on 5 occasions and in December they fell to $2^{\circ} \mathrm{C}$ or below on 5 occasions. Over 300 pups were dead or dying in early December, and overall deaths were estimated at 500 . Such mortality is likely to have a significant effect on the population, which had already declined from 100000 to 65000 since the 1960s (Bourne \& Hamilton-Smith 2007).

\section{Extreme heat: Pteropus alecto and P. poliocephalus}

On 12 January 2002 in northern New South Wales, ambient temperatures of over $42^{\circ} \mathrm{C}$ resulted in the deaths of over 3500 individuals in 9 mixed-species colonies of Pteropus alecto and P. poliocephalus. In one colony alone, 5 to $6 \%$ of the bats present died from hyperthermia. The temperature extreme had a greater effect on the tropical black flying fox P. alecto, 10 to $13 \%$ of which died, compared with $<1 \%$ of the more temperate grey-headed flying fox $P$. poliocephalus. Mortality mainly affected dependent young (23 to $49 \%$ of deaths) followed by adult females (10 to $15 \%$ ) and $<3 \%$ of adult males (Welbergen et al. 2008).

This closely observed event led to documentation of similar occurrences, and it became apparent that more than 30000 Pteropus spp. have died during 19 temper- ature extremes, 24500 of which were $P$. poliocephalus (listed as Vulnerable in Australia). P. alecto was relatively less affected because most die-offs occurred below its southern distribution limit. However, the fact that this limit is increasing southward also increases the likelihood of die-offs occurring in this species (Welbergen et al. 2008).

\section{Cyclones}

The increased frequency of extreme weather events (hurricanes and typhoons) in the tropics has a marked deleterious effect on bat populations, particularly those that roost in trees on islands, as a direct consequence of tree loss and by increased hunting by island inhabitants experiencing food shortages.

Cyclones in the western Indian Ocean have long threatened endemic pteropodids such as Pteropus rodricensis in the Mascarene Islands, the population of which was halved by a single cyclone (Carroll 1988). In the Samoan Islands, the populations of $P$. samoensis and $P$. tonganus declined by 80 to $90 \%$ as a result of cyclones in the early 1990s (Craig et al. 1994). These cyclones had a differential impact on the 2 species, reflecting differences in habitat use and susceptibility to hunting (Pierson et al. 1996).

Such differential effects also have been documented in the Caribbean where Hurricane Hugo (1989) significantly reduced populations of the dominant frugivore Artibeus jamaicensis, which were slower to recover than those of Brachyphylla cavernarum, so that the latter dominated the frugivore ensemble $5 \mathrm{yr}$ after the hurricane (Pedersen et al. 2009). The species-specific effects of hurricanes are further revealed by Gannon \& Willig (2009) for the bats of Puerto Rico. The rate of recovery of cave-roosting $A$. jamaicensis populations depended on the severity of the hurricane. Recovery occurred more rapidly after Hurricane Hugo (1989, category 5) than after Hurricane Georges (1998, category 3), likely because $A$. jamaicensis benefits from the proliferation of the pioneer plant species on which it feeds (Fig. 3). In contrast, populations of the tree-roosting Stenoderma rufum declined gradually after Hurricane Hugo and appeared to suffer far more from subsequent alteration of the habitat than from direct hurricane mortality.

\section{Other possible effects of climate change}

Bats may also be affected by other factors involved in climate change, although evidence to date is somewhat anecdotal. Extreme precipitation may depress foraging activity and lead to desertion of the young 


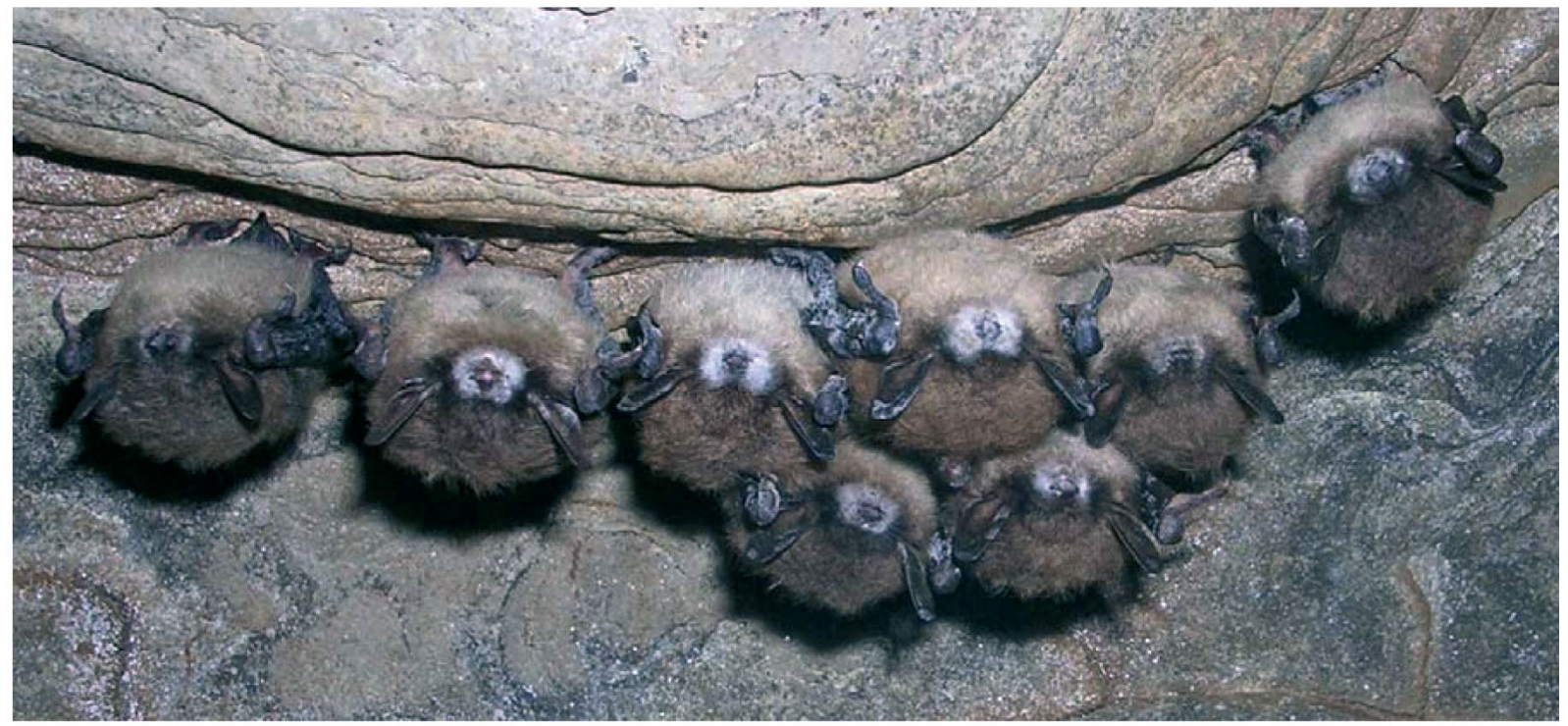

Fig. 2. Cluster of little brown bats Myotis lucifugus showing symptoms of white-nose syndrome. The syndrome has been associated with recent mass deaths of bats in the northeastern USA, though it may be a secondary consequence of other environmental stressors. Signs of disease in bats may be indicators of environmental stress. Photo credit: Al Hicks, New York Department of Environmental Conservation

(Bat Conservation Trust 2007). Additionally, sea level rise may reduce access to some cave roosts, such as those on the Kenyan coast, where the entrances to coastal caves are presently partially submerged (McWilliam 1982).

Bat populations are likely to be affected directly by climate change, but may also suffer from indirect effects as changes in the means of energy production occur in response to the need to reduce carbon emissions. In particular, the development of wind energy facilities in Australia, Europe and North America has led to unexpectedly large numbers of migratory bats being killed (Brinkman 2006, Kunz et al. 2007, NRC 2007, Arnett et al. 2007, 2008, Baerwald et al. 2008).
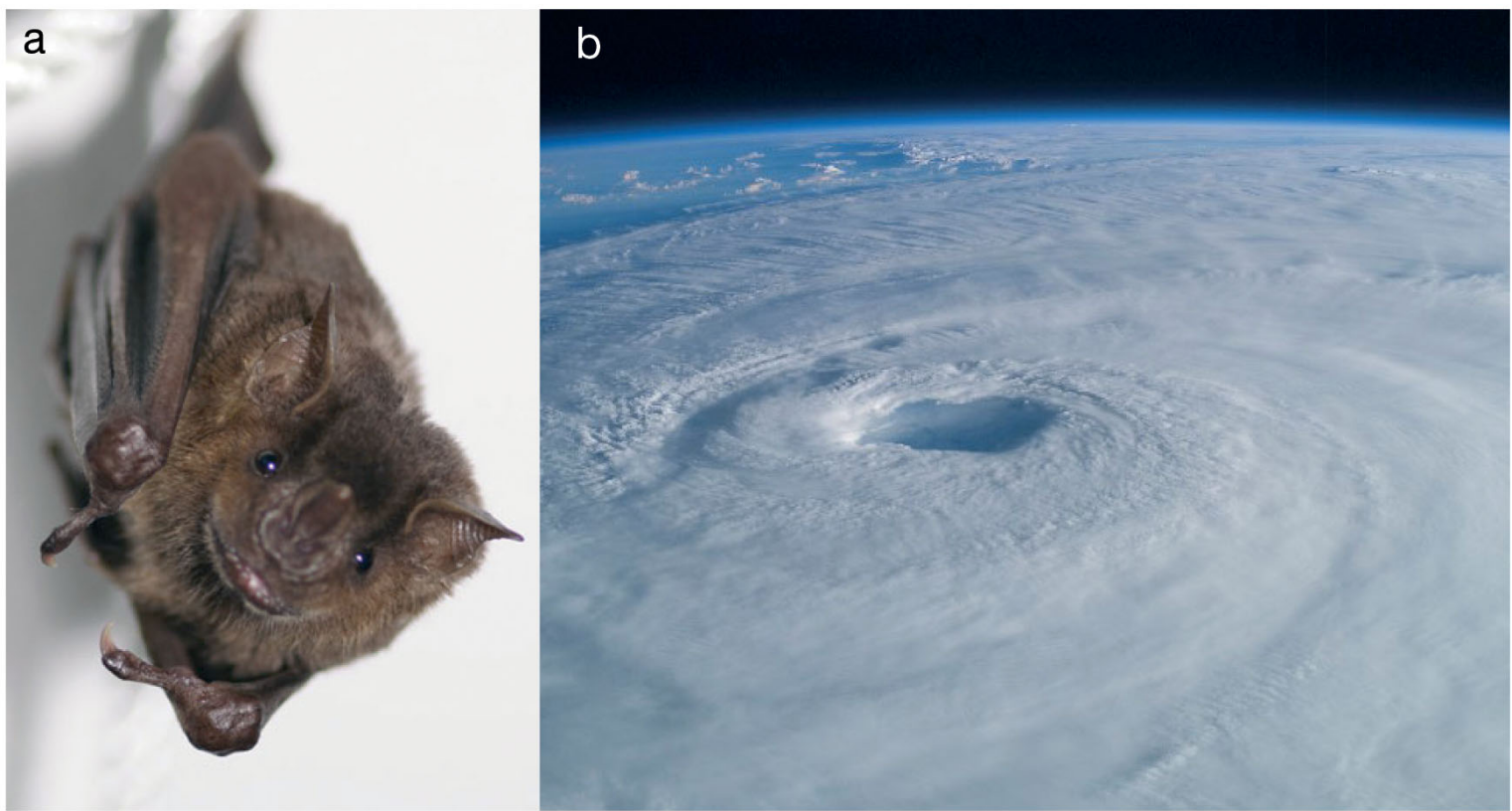

Fig. 3. Bats are sensitive to the effects of habitat disturbance caused by major climatic events such as hurricanes. Populations of Artibeus jamaicensis (a) recovered more slowly after Hurricane Hugo in 1989 (b) than those of Brachyphylla cavernarum, so that the latter dominated the frugivore guild 5 yr after the hurricane. Photos: (a) T. Schountz; (b) NASA 
Efforts are needed to find ways to reduce the impacts of these facilities on bats, either by developing acoustic deterrents or by increasing the turbine cut-in speed (the wind speed at which electricity enters the power grid) during migratory periods (Kunz et al. 2007, NRC 2007). Recent research in Canada and Germany has indicated that bat fatalities can be reduced significantly when turbine cut-in speeds are increased slightly (E. B. Arnett, R. M. R. Barclay, O. Behr pers. comm.).

\section{Habitat and landscape change}

Habitat change has affected bats in many ways. Below we review the roles of several of the key anthropogenic changes that have occurred recently, especially focusing on urbanisation, changes in water quality, agricultural intensification, forest disturbance and roost loss.

Urbanisation, industrialisation and heavy metal pollution

Changes in land-use practices may also affect the species composition of local and regional ecosystems, especially those associated with conditions and structures of urbanisation (Rydell 1992, Keeley \& Tuttle 1999, Kunz \& Reynolds 2003, Kunz et al. 2008). Light pollution might affect bats in different ways. For example, emergence may be extended and infant growth retarded by house lights in some slow-flying bat species adapted to more forested habitats (Boldogh et al. 2007). In contrast, some populations adapted to foraging in open spaces (e.g. Pipistrellus spp. in western Europe) may benefit from feeding on insects attracted to streetlights. Arlettaz et al. (2000) suggested that this increase may have contributed to the decline in Rhinolophus hipposideros, which rely on the same categories of insect prey - namely dipterans and lepidopterans. The increasing use of bridges and buildings, including houses designed specifically for bats, has led to changes in geographic distributions and local population densities of some bat species (Tuttle \& Hensley 1993, Kunz \& Reynolds 2003). Consequently, some species that formerly only roosted in caves and tree cavities on a seasonal basis have become more abundant and occupied some roosts on a yearly basis (Kunz 1982, Kunz \& Reynolds 2003, Ormsbee et al. 2007). The longterm consequences of this shift in roosting habits on local species composition in temperate and tropical ecosystems remain to be determined, especially given the relatively ephemeral nature of these human interventions.

Bats may also be negatively affected by recent increases in road traffic. Greater mouse-eared bats
Myotis myotis spend less time foraging when subjected to traffic noise in laboratory conditions, presumably because the noise masks rustling noises made by moving insects that these bats normally detect by passive listening (Schaub et al. 2008). Bats may also be killed by collisions with motor vehicles on busy roads (Russell et al. 2009, this Theme Section).

Pollution by heavy metals is often associated with urbanisation. Cadmium, lead and mercury are the most commonly reported heavy metals associated with toxic effects on wildlife (O'Shea \& Johnson 2009). High concentrations of cadmium have been reported in the guano of gray bats Myotis grisescens in the USA (Clark 1988a,b). Several studies have reported mercury concentrations in insectivorous bats (O'Shea \& Johnson 2009) but none have determined the concentration of methyl mercury. When methylated, often through microbial processes, mercury becomes highly toxic and concentrates through food webs to a greater extent than in its elemental form. Lead poisoning has been well-documented in both wild and captive Old World fruit bats based on lead concentrations in target organs, histopathology, morbidity and mortality (Zook et al. 1970, Sutton \& Wilson 1983, Skerratt et al. 1998). Concentrations of other heavy metals and toxic elements have been reported in bats, but only in a few cases have shown harmful effects (O'Shea \& Johnson 2009).

\section{Water quality}

Riparian habitats are prime foraging areas for insectivorous bats (e.g. Vaughan et al. 1996, Fukui et al. 2006); these rivers and lakes support large numbers of insects. However, deterioration in water quality may occur because of agricultural runoff and industrial pollution (Mason 1997). High input of organic matter and toxins such as ammonia into water courses from sewage treatment plants may lead to eutrophication that can in turn affect the invertebrate community in rivers. For example, the biomass and diversity of insects emerging from rivers is lower downstream of sewage outputs (Whitehurst \& Lindsey 1990).

Vaughan et al. (1996) measured bat activity above and below sewage outfalls as a model system to test the hypothesis that widespread declines in water quality may reduce bat activity. Sites downstream of sewage outputs had overall $11 \%$ fewer bat passes and $28 \%$ fewer buzzes than upstream sites; the reduction in activity was especially noticeable in Pipistrellus (Vaughan et al. 1996). Myotis had higher feeding activity downstream (Vaughan et al. 1996), possibly reflecting the presence of pollution-tolerant insects such as some chironomid species that may benefit from 
eutrophication (Mason 1997). Vaughan et al. (1996) showed that deterioration in water quality can have negative impacts on bat activity and foraging, highlighting that bats can be used as bioindicators of water quality and long-term declines in water quality may have contributed to declines in bat populations in Britain.

Kalcounis-Rueppell et al. (2007) investigated the effects of effluent from a wastewater treatment plant (WWTP) on foraging activities of bats and insect abundance along urban streams in North Carolina, USA. More bat passes of Eptesicus fuscus (a habitat generalist) were recorded upstream of the WWTP, whereas activity of Perimyotis subflavus (a riparian habitat specialist) was higher downstream, suggesting that $P$. subflavus may be tolerant of or even benefit from anthropogenic input into the watershed which may increase the availability of some prey groups (Kalcounis-Rueppell et al. 2007).

There is little evidence that eutrophication of fresh waters is harmful to bats; in fact it may be responsible for the apparent increases in populations of Myotis daubentonii in Europe (Kokurewicz 1995). In a study designed to test this hypothesis, Racey et al. (1998) found little difference between the numbers of bats and insects foraging over a small eutrophic river and a large oligotrophic one.

Park \& Cristinacce (2006) investigated the effect on foraging bats of phasing out percolating filter beds, which provide breeding opportunities for dipterans, in favour of activated sludge, for treating human sewage. They demonstrated that the biomass of insects and activity of Pipistrellus spp. were significantly higher at filter beds than at activated sludge systems, and suggested that the current preference for the latter is likely to reduce the value of treatment works as foraging sites for bats.

\section{Agricultural intensification and pesticide use}

Changes in agricultural practices are occurring worldwide, and intensification is ongoing as the human population increases in number. Most research on the effects of agricultural intensification has been performed in developed nations, though the impacts of intensification will no doubt be felt on a global scale.

Agricultural intensification is recognised as having had major detrimental effects on biodiversity in western Europe since the mid-20th century (Robinson \& Sutherland 2002). The effects of agricultural intensification can be large in scale. For example, $76 \%$ of the land in Britain is currently used for agriculture. Intensification involves the increased production of agricultural commodities per unit area (Donald et al. 2001) and involves processes such as increased mechanisation and the use of synthetic chemical fertilizers and pesticides. Traditional rotations in farm management have declined, and hedgerows and field margins have been removed (Robinson \& Sutherland 2002). The effects of agricultural intensification have been marked for granivorous birds: 24 of 28 farmland bird species declined between 1970 and 1990 (Fuller et al. 1995b). Increased pesticide use can further reduce food available for insectivorous bats, and the removal of hedgerows and field margins will take away valuable foraging and commuting habitats, as well as reducing the availability of important habitats for their prey (Fig. 4). Thus, it has been hypothesised that agricultural intensification is a major cause of the declines in bat populations in Europe during the latter half of the 20th century (Stebbings 1988).

Long-term historical data are not available to test this hypothesis directly, but an indirect test is possible by comparing the abundance of nocturnal insects and the activity and foraging rates of bats on contemporary organic and conventional farms. In organic farming, the use of synthetic fertilizers, pesticides, genetically engineered seeds, growth regulators and food additives for livestock are excluded. Comparisons between matched pairs of organic and conventional farms are therefore useful for investigating the impact of agricultural intensification on biodiversity.

Nocturnal insect abundance, species richness and moth species diversity were higher on organic farms than on their matched conventional counterparts (Wickramasinghe et al. 2004). Five of the major insect prey groups eaten by bats (carabid beetles, noctuid moths, geometrid moths and chironomid and ceratopogonid flies) were more abundant on organic farms (Wickramasinghe et al. 2004). These data suggest that the prey base of nocturnal insects available for bats is depleted on conventional compared with organic farms, thus, providing support for findings from other studies that show increased numbers and diversity of other insect taxa on organic farms (Bengtsson et al. 2005, Fuller et al. 2005, Hole et al. 2005). Moreover, bat activity was $61 \%$ higher and foraging activity (counts of feeding buzzes) was $84 \%$ higher on organic farms than on conventional ones (Wickramasinghe et al. 2003). Species composition was similar in both situations, although horseshoe bats Rhinolophus spp. were only detected on organic farms (Wickramasinghe et al. 2003). The study emphasised that bats are likely victims of agricultural change and important bioindicators of intensification that can also track changes in their ecologically important prey base. The finding of increased bat activity on organic farms was also determined in an independent study by Fuller et al. (2005). 

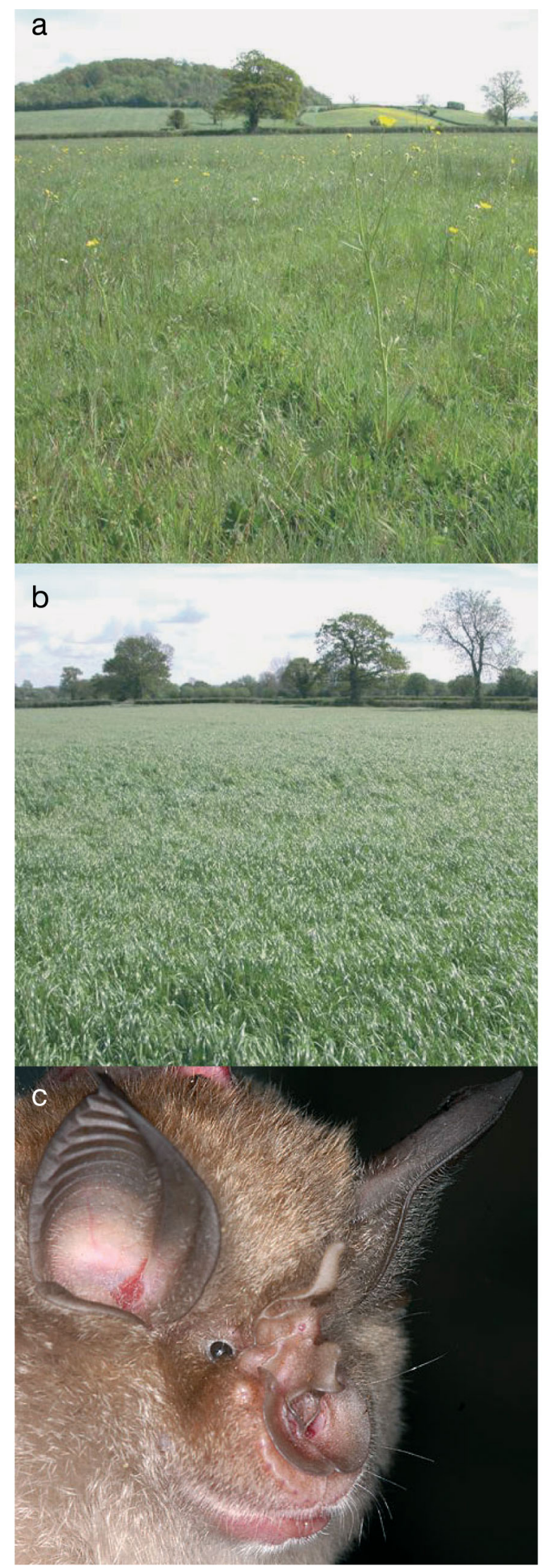

Understanding the mechanisms contributing to these trends is important. Although the paired organic and conventional farms in the study by Wickramasinghe et al. (2003) were matched as closely as possible and were similar in their areas of pastoral, arable, woodland and water habitats, in habitat richness and in farm size, organic farms had significantly higher hedgerows. Thus, it was unclear whether hedgerow structure or agrochemical use was the important characteristic driving differences in bat activity and insect abundance between the 2 farm types. Notwithstanding, bats and their insect prey respond in similar ways to differences in agricultural practice, suggesting that changes in bat populations may reflect more widespread biotic change.

Possible mechanisms driving these differences were investigated further by Pocock \& Jennings (2008) who documented differences in the sensitivity (measured by the difference of log counts at paired sites) of insectivorous mammals and their prey to proxies of intensification (representing use of agrochemicals, the switch in grass production from hay to silage and boundary loss). Bats were especially sensitive to boundary loss, suggesting that hedgerow differences may be an important driver of their reduced activity and feeding rates on conventional farms (Pocock \& Jennings 2008). Hedgerows are important commuting routes for bats (Verboom \& Huitema 1997, Downs \& Racey 2006) and serve as shelterbelts where swarms of aerial insects congregate (Lewis \& Dibley 1970), forming food patches for bats. Insects were more sensitive to increased agrochemical input than were their mammalian predators (including bats) (Pocock \& Jennings 2008). The latter authors (2008) emphasised that different taxa respond in different ways to specific aspects of intensification, and the choice of suitable bioindicators should be made with care. Indeed, the sensitivity of a taxon to one aspect of intensification is often a poor predictor of its sensitivity to another. It is clear that no single taxon can be an indicator of all aspects of intensification, further indicating that bioindicator studies in response to agricultural intensification require studies involving multiple taxa (Pocock \& Jennings 2008).

Pesticide use is also an important component of agricultural intensification. Although the primary purpose

Fig. 4. Bats are sensitive to the effects of agricultural intensification. Many hay meadows rich in plant species such as this one on an organic farm (a) have been replaced by intensively managed silage in Great Britain (b). Bat activity and counts of feeding buzzes were found to be higher on organic than conventional farms (Wickramasinghe et al. 2003), and horseshoe bats such as Rhinolophus ferrumequinum (c) were only recorded on organic farms surveyed. Photos: (a, b) N. Jennings; (c) G. Jones 
of agricultural pesticides is the reduction of insect numbers, direct evidence that such reduction in insect food supply limits the populations of insectivorous bats is not available. There is, however, direct evidence that agricultural pesticides ingested with insects carry sublethal levels that were responsible for heavy mortality of Tadarida brasiliensis in New Mexico (Geluso et al. 1976, 1979, Clark 1981). Pesticides are mobilized during lactation and transferred in the milk to the young that die as a result (Geluso et al. 1981).

Jefferies (1972) showed that bats taken from one of the most intensively farmed areas of the UK were more heavily contaminated with residues of DDT than were either insectivorous or carnivorous birds. Laboratory experiments showed that bats were more sensitive to DDT than were other mammals, and it was metabolized more slowly in bats than in passerine birds. Bats carried one-third of the lethal level of organochlorine insecticides, but this rose to close to lethal levels following hibernation. These results suggest that organochlorine residues could have caused population declines in bats (Jefferies 1972).

In the USA, many endangered Myotis grisescens were found dead with lethal brain levels of Dieldrin in 2 colonies (Clark et al. 1978a), and high levels of DDT found in skin samples have been linked to the decline of Tadarida brasiliensis at Carlsbad Caverns, New Mexico during the 1950s and 1960s (Clark 2001). In Australia, high tissue levels of DDT were detected in Miniopterus schreibersii, even in young bats that had not left the maternity roosts. Such high levels of DDT were the suspected cause of several mass die-offs in this species (Dunsmore et al. 1974). However, in Spain, Hernández et al. (1993) found that chlorinated hydrocarbon residues in bats were at much lower concentrations than the estimated lower lethal levels.

Historically, chlorinated hydrocarbons were used to exclude bats from buildings in the USA, but this increased mortality of adults and volant young when fat stores were metabolized (Kunz et al. 1977, Clark et al. 1978b). Similarly, these pesticides have been used as remedial timber treatments within roof spaces and have led to the deaths of bats roosting there (Voute 1981, Racey \& Swift 1986). In the USA and the UK, owing largely to pressure from conservationists and environmentalists, most of these highly toxic chemicals have been replaced by synthetic pyrethroids and other alternatives with much lower mammalian toxicity (Racey 2000). Although Clark (1981, 1988a,b) suggested that pesticides might have subtle but important effects on bat physiology, the sublethal effects of chlorinated hydrocarbons have rarely been documented (Swanepoel et al. 1999). The residues of such pesticides are also commonly found in the tissues of bats in the developing world (McWilliam 1994).
In recent years, synthetic pyrethroid insecticides have become increasingly used to control insect pests (Hirano 1989, O'Shea \& Clark 2002). Pyrethroid compounds were initially extracted from chrysanthemum flowers in the $1800 \mathrm{~s}$, but most are now manufactured in several different synthetic forms. Most are lipophilic, highly toxic to aquatic organisms and are rapidly metabolized. They appear to exhibit low toxicity in laboratory mammals (Peterle 1991). Pyrethroids are neurotoxic and the mode of action resembles that of the organochlorine DDT. However, some pyrethroids may persist in the environment and adversely affect bats, particularly chlorinated forms such as cypermethrin (Clark \& Shore 2001). Apart from the work of Racey \& Swift (1986) there has been little research on the effects of pyrethroids on bats or their insect prey. With the growing use of these compounds, research should be undertaken to explore their direct impact on bats and the insects upon which bats feed (O'Shea \& Johnson 2009).

\section{Deforestation}

Rapid rates of deforestation are of major conservation concern, especially in tropical environments (Ewers 2006). Most research on the effects of disturbance on bats in tropical forests has been conducted in the neotropics, and some of the key findings are highlighted below.

Latitudinal gradients of biodiversity in New World bats are quite steep with regard to taxonomic (Willig \& Selcer 1989, Willig \& Sandlin 1991, Stevens \& Willig 2002), functional (Stevens et al. 2003) and phenetic (Stevens et al. 2006) components, all attaining maxima in equatorial regions. The family Phyllostomidae differentially contributes to these patterns, as it is the most diverse bat family in the neotropics (Rex et al. 2008). Phyllostomids eat nectar, pollen, fruit, insects, small vertebrates and even blood (Gardner 1977). Their diversity and differential dependence on forested environments potentially makes them key indicators of disturbance in neotropical forests (Fig. 5).

Fenton et al. (1992) captured species in the subfamily Phyllostominae (whose species eat mainly animals, though sometimes they eat more fruit than animals) more often in forested than in deforested sites in Mexico, and considered phyllostomine bats as suitable indicators of habitat disruption caused by deforestation. They also related vegetation structure to the richness and diversity of bat communities in Mexican rainforests, and showed that species richness, the number of rare species and diversity were all positively associated with vegetation indices that were suggestive of low levels of forest disturbance. These results corrobo- 
rate the value of the species in this subfamily as bioindicators of habitat disruption in neotropical forests. Indeed, many phyllostomine bats are specialised in dietary and roosting habits, and thus a large number of species may reflect a wider range of niche dimensions than are available in undisturbed habitats (Kalko et al. 1996, Kalko 1998, Medellín et al. 2000, Kalko \& Handley 2001, Patterson et al. 2003).

Willig et al. (2007) documented population-level responses of 24 common phyllostomid bats to habitat alteration in lowland Amazonia in the environs of Iquitos, Peru. In this region, like in much of the western Amazon, human disturbance (Maki et al. 2001) primarily parallels navigable rivers and roads, where understory vegetation is removed and most of the trees are felled and burned prior to planting with pineapple, plantain or manioc. The resultant agricultural clearings (chacras) are generally small in extent ( 1 ha). They are farmed until the soil is no longer fertile, after which they are abandoned and regenerate into early successional forest (purma). Frugivorous species dominated chacra, purma and undisturbed forest habitats (Willig et al. 2007). Nonetheless, 8 phyllostomid species responded to habitat conversion. Four (Phyllostomus discolor, Sturnira lilium, S. tildae, and Uroderma bilobatum) attained highest abundances in chacra. Two species (Tonatia saurophila and Mesophylla macconnelli) attained highest abundances in mature forest, and Carollia benkeithi was most abundant in purma. Carollia sp. attained higher abundances in purma and chacra than in mature forest. In a comparison of temporal activity among the 3 habitat types for the 8 most common phyllostomids, Presley et al. (2009) found no differences between closed forest and purma, but significant differences between agricultural (chacra) and forested (purma and closed canopy site) areas for 5 species (Artibeus lituratus, A. obscurus, A. planirostris, C. perspicillata and $R$. pumilio). Taken together, these results suggest that bats maybe sensitive bioindicators of anthropogenic activities because their abundances and behaviours are affected by disturbance and recovery processes even at small spatial scales.

It is important to appreciate that the level of disturbance may affect patterns of species richness and diversity in neotropical forests, and probably in other ecosystems as well. Moderate levels of disturbance in some neotropical forests may increase habitat heterogeneity and thus may increase bat diversity (Gorresen \& Willig 2004). Responses to fragmentation also differ among guilds: in Guatemala large frugivorous bats formed a higher proportion of the nightly catch in continuous forest, whereas small frugivores were proportionally more abundant in fragments. Thus, the relative abundances of these 2 ensembles, which feed on large fruits of mature trees and small fruits that occur in early successional changes respectively, may allow a rapid assessment of forest disturbance (Schulze et al. 2000). More recently, Klingbeil \& Willig (2009) showed that population-level responses to fragmentation in lowland Amazonia (peri-Iquitos area) by frugivorous bats (e.g. stenodermatines) differed from that of gleaning animalivores (e.g. phyllostomines). Frugivores responded to compositional metrics (i.e. forest cover, patch density, mean patch size and patch diversity), whereas gleaning animalivores responded to configurational metrics (i.e. edge density, mean patch shape, mean proximity, mean nearest neighbour distance). Moreover, indices of community structure (e.g. species richness, evenness, dominance, diversity and rarity) only responded to configurational metrics.

Studies of bats suggest that low impact logging in lowland Amazonia (Tapajos National Forest of Brazil) might represent a sustainable use of tropical forests for timber extraction without appreciable negative effects on the bat fauna (Castro-Arellano et al. 2007, Presley et al. 2008). Although compositional (species abundance distributions) and structural (rank abundance distributions) aspects of assemblages differed between cut and control forests, most of the differences could be attributed to the decrease in relative abundance of Carollia perspicillata and the increase in relative abundance of Artibeus lituratus in cut forest compared to control forest. However, the number of rare species in cut forest was much less than that in control forest (i.e. loss of 13 species). If sufficient primary forest exists in close vicinity to these managed areas, rescue effects will likely countermand local extinctions. Thus, these studies document the differential responses of bats at the level of populations, ensembles and assemblages to anthropogenic disturbance, and suggest that population and community metrics would be useful as bioindicators of even subtle changes associated with the removal of $<19 \mathrm{~m}^{3}$ of tree biomass per hectare.

Roost loss

Timber harvesting and agricultural practices have adversely affected bat populations in many parts of the world (Lacki et al. 2007). Clearing of rainforests or temperate-zone old-growth forests (with selective harvesting of snags) has resulted in the loss of crevice, cavity and foliage roosts, as well as important foraging habitats. Consequences are likely to be most serious for species such as the neotropical Vampyrum spectrum or the North American Lasionycteris noctivagans, which appear to require tree hollows for roosting (Kunz \& Lumsden 2003, Barclay \& Kurta 2007). Several species that in the past most likely occupied hollow trees now regularly use man-made structures, where they are 


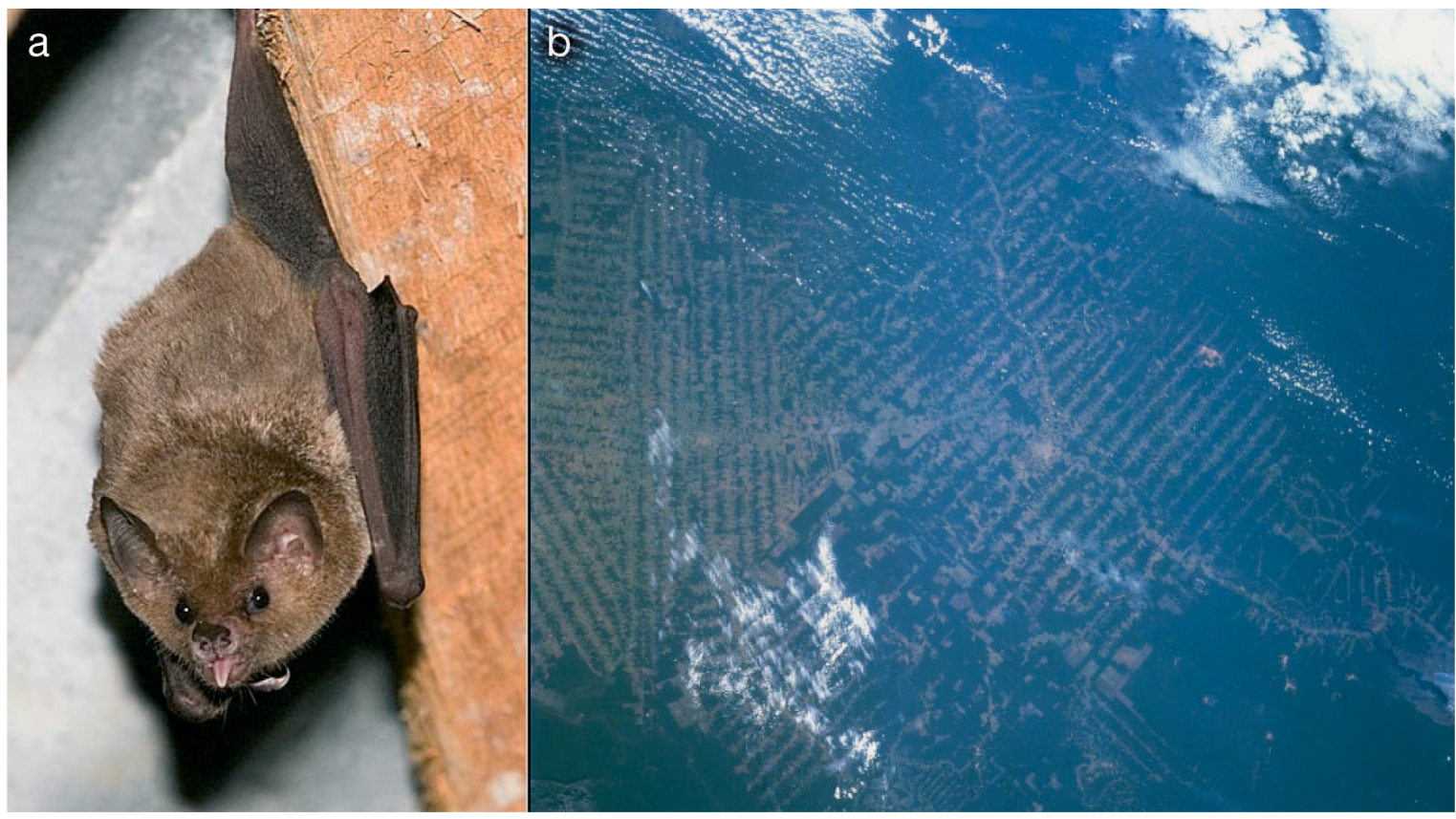

Fig. 5. Bats are indicators of habitat disturbance in neotropical rainforests. The phyllostomid Glossophaga soricina (a) prefers small agricultural clearings (chacras) in the lowland Amazon of Peru. Deforestation and fragmentation of forest patches is a major problem in the neotropics. The satellite image (b) illustrates the deforested frontier in Rondonia State of west-central Brazil, showing a patchwork of clearcut swaths (light areas) expanding into the Amazon rainforest (darker patches). The forest here is cleared for ranching and timber. Photos: (a) G. Jones; (b) NASA

often not welcome and may face exclusion or eradication. Man-made structures such as barns are being converted into living spaces at a rapid rate (Kunz \& Reynolds 2003), and caves and mines often experience high levels of disturbance from tourism.

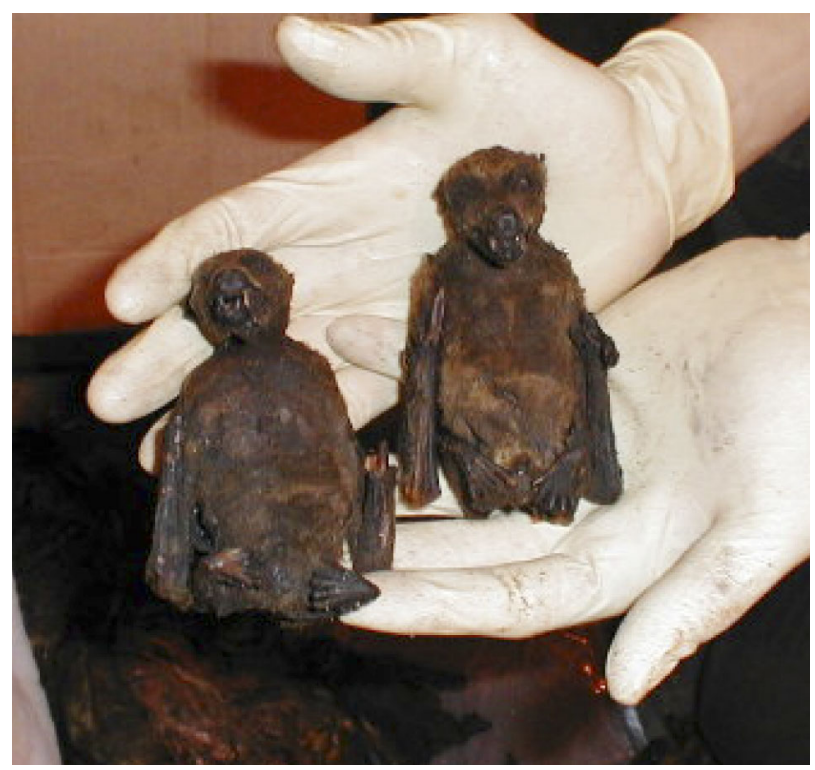

Fig. 6. Bats are indicators of the pressures of overhunting for bushmeat. These fruit bats were in a confiscated consignment of bushmeat from Africa. Photo: US Fish and Wildlife Service

\section{Hunting}

Although hunting of pteropodids for food is widespread (Mickleburgh et al. 2009), there have been few attempts to harvest bats sustainably (Halstead 1977). Overhunting has resulted in the extinction of Pteropus subniger in Mauritius and Réunion (Cheke \& Dahl 1981) and has contributed to the local extinction of a dozen other congeners from Indo-Pacific islands (Rainey 1998). Hunting continues to be a key threat to pteropodids (Fig. 6), including species on islands in the Indian and Pacific Oceans such as P. rufus (Racey et al. 2009, Wiles \& Brooke 2009).

Human consumption remains a major factor affecting bat populations on Indo-Pacific islands and in adjacent areas of Asia, a practice that has led to international trade in fruit bats into Guam and the adjacent Commonwealth of the Northern Marianas (CNMI) (Rainey 1998, Wiles 1992). Hunting by Guamanians reduced the population of Pteropus mariannus on the island to a few hundred individuals within the confines of the US military base and, perhaps, contributed to the extinction of $P$. tokudae. In Palau, P. mariannus was intensively harvested until 1994, with between 10000 and 16000 bats exported annually to Guam and the CNMI (Wiles et al. 1997). Brooke \& Tschapka (2002) documented the unsustainable hunting of $P$. tonganus 
on Niue Island in the South Pacific, stemming from the belief of islanders that taboo areas on the island, which they did not enter, harboured an inexhaustible supply of bats, $>1500$ of which were shot when the population was estimated at between 2000 and 4000 ind. Jenkins \& Racey (2008) reported that although the endemic Pteropus rufus, Eidolon dupreanum, Rousettus madagascariensis and Hipposideros commersoni were the most commonly eaten bats in Madagascar, a wide range of small insectivorous bats also are taken, and the high harvesting represents a serious threat to local populations. The killing of the molossid Cheiromeles torquatus for food in Borneo is also causing serious concern (Hutson et al. 2001), and the unsustainable exploitation of insectivorous bats for food in Laos has been described by Francis et al. (1999), with thousands of Tadarida being harvested during exit from a cave and then subsequently smoked for sale. In one instance, 3000 ind. were sold to occupants of a single passing truck.

\section{Disease}

High fatalities observed in bats, if associated with diseases, may provide an early warning of environmental links among contamination, disease prevalence and mortality. Increased environmental stress can suppress the immune systems of bats and other animals, and thus one might predict that the increased prevalence of diseases is a consequence of altered environments. Bats are reservoirs of several pathogens whose spread may be related to physiological stress associated with habitat loss or alteration (Fenton et al. 2006). The recent die-offs of bats presenting with white-nose syndrome (Blehert et al. 2009) may relate to increased levels of environmental stress, perhaps as a consequence of increased arousals and hence energetic stress during hibernation, rendering the bats susceptible to fungal infection.

In their comprehensive review of viral infections of bats, Messenger et al. (2003) noted that infectious disease has rarely been documented as a large-scale cause of mortality in any bat population and thus is seldom mentioned as a major issue. This contrasts with the situation in birds where, for example, the impact of West Nile virus on North American populations has recently been documented (LaDeau et al. 2007). Messenger et al. (2003) noted the few documented cases of bat mortality in which disease has been implicated. For example, several thousand Tadarida brasiliensis died in Carlsbad Caverns, New Mexico in August 1955 and 1956; the fact that half of the 20 bats sampled in 1955 were rabies-positive led to the hypothesis that rabies was the overall cause of mortality (Burns et al. 1956). However, inclement weather during migration was subsequently linked to the deaths in 1956 (Constantine 1967). The only other mass mortality attributed to rabies was several hundred Epomops dobsoni in southern Africa, 10 to $15 \%$ of which were confirmed to be infected with Lagos bat virus (King et al. 1994).

Pierson \& Rainey (1992) described episodes of apparent epidemic disease in Pacific flying fox populations, including mass deaths of Pteropus mariannus in Micronesia in the 1930s at the same time as measles affected the human population. An epidemic of unknown aetiology was also suspected of depleting populations of $P$. tonganus in Fiji during the 1940s. More recent episodes occurred on the Admiralty Islands when many P. neohibernicus were found dead in 1985 (Flannery 1989); a similar incident involved $P$. rayneri in the Solomon Islands.

Since Messenger et al. (2003) reviewed the subject, Calisher et al. $(2006,2008)$ have updated the list of viruses isolated from bats, Breed et al. (2006) have reviewed the association between henipariviruses and bats, Harris et al. (2006) have reviewed the prevalence of European bat lyssaviruses and Demma et al. (2009) have summarized recent information on the prevalence of rabies and other diseases associated with bats. Other studies have reported the occurrence of antibodies to SARS-like coronaviruses in several species of rhinolophids in China (Lau et al. 2005, Li et al. 2005) and to Nipah, Hendra and Tioman viruses in the 3 endemic Malagasy pteropodids (Lehlé et al. 2007). Evidence of asymptomatic Ebola virus infections has been found in 3 species of pteropodids in West Africa (Leroy et al. 2005). Most of these studies have been driven by concerns about the health of humans, great apes or livestock and little evidence has emerged about the effects of virus infections on the bats themselves, although some fitness costs must be assumed. The most important fact to emerge, however, is that the same bats may be seropositive to rabies-like viruses in successive years and the disease is not necessarily fatal in these animals (O'Shea \& Bogan 2003, Amengual et al. 2007).

Bats represent a potential epidemiologic reservoir of transmission of leptospirosis to humans, especially in the tropical Amazon. Indeed, a diverse group of leptospires occurs in peri-Iquitos bat populations including Leptospira interrogans (5 clones), L. kirschneri (1 clone), L. borgpetersenii (4 clones), L. fainei (1 clone) and 2 previously undescribed leptospiral species (8 clones) (Matthias et al. 2005). The detection in bats of the L. interrogans serovar Icterohemorrhagiae, a leptospire typically maintained by peridomestic rats, suggests a rodent-bat infection cycle in Iquitos. The maintenance of a genetically diverse group of leptospires in bats suggests that they may be capable of transmitting 
leptospirosis to humans, and thus species of public health concern in the tropics (Bharti et al. 2003).

Mass deaths of Miniopterus schreibersii were reported in caves across southern France in 2002, extending into Spain and Portugal. Although the extent of mortality was thought to have reduced the population by 60 to $65 \%$, the cause was unclear, although herpes virus was isolated from bat lungs (Roue \& Nemoz 2004). Other bat species inhabiting the caves were thought to be unaffected (Roue \& Nemoz 2004). More recently, 8 novel herpes viruses have been isolated from 7 European bat species (Wibbelt et al. 2007). Although half the bats examined showed signs of pneumonia, none of the viruses could be related consistently to a pulmonary lesion, although an aetiological association between the 2 could not be excluded. Bats are reservoirs of several diseases that can be fatal to humans, including rabies and Ebola (Messenger et al. 2003). Bat populations may come into increasing contact with humans as habitat is destroyed and human populations encroach into pristine habitats, increasing the risk of spillover of infections into humans. An increased incidence of disease in bats may therefore be an important bioindicator of habitat degradation in general.

\section{CONCLUSIONS}

Bats are excellent indicators of human-induced changes in climate and habitat quality. They show functional and taxonomic diversity and are widely distributed. Many bats fulfill vital ecosystem services, and declines in bat populations often reflect features of habitat deterioration that have impacts on a wide range of taxa. Bat populations show responses to environmental stressors ranging from alterations in habitat quality to climate change as well as direct exploitation. They are reservoirs of a wide range of diseases whose spread and spillover may be related to habitat deterioration and climate change. Bats have taxonomic stability, and can be monitored by a range of methods (Kunz \& Parsons 2009). The importance of bats as bioindicators is already being recognised. For example, in May 2008 the UK government adopted bats into their suite of biodiversity indicators of the sustainability of lifestyles to meet targets under the Convention on Biological Diversity. EUROBATS has a 'Bats as Indicators' Intersessional Working Group that aims to take forward opportunities to use bats as biodiversity indicators. It is now time to 'seize the night' and to develop a global monitoring programme for bat populations, involving standardised methodology that can be applied in both New and Old World situations, so that the value of bats as bioindicators can be fully realised.
Acknowledgements. This paper evolved from a workshop on 'Protocols for Monitoring Bat Species in TEAM sites' hosted by Conservation International in May 2007. We thank K. Jones and S. Andelman for their organisational input and stimulating discussions. Other workshop participants-E. Kalko, T. Kingston, S. Parsons, J. Arroyo-Cabrales and L. Fernando Aguirre-provided important discourse that helped shape our ideas. Two anonymous referees and T. Gardner provided valuable comments on an earlier draft.

\section{LITERATURE CITED}

Agosta SJ (2002) Habitat use, diet, and roost selection by the big brown bat (Eptesicus fuscus) in North America: a case for conserving an abundant species. Mammal Rev 32: 179-198

Agosta SJ, Morton D (2003) Diet of the big brown bat, Eptesicus fuscus, from Pennsylvania and western Maryland. Northeast Nat 10:89-104

Allen TFH, Hoekstra TW (1993) Towards a unified ecology. Columbia University Press, New York

Alleva E, Francia N, Pandolfi M, De Marinis AM, Chiarotti F, Santucci D (2006) Organochlorine and heavy-metal contaminants in wild mammals and birds of Urbino-Pesaro Province, Italy: an analytic overview for potential bioindicators. Arch Environ Contam Toxicol 51:123-134

Amengual B, Bourhy H, López-Roig M, Serra-Cobo J (2007) Temporal dynamics of European bat lyssavirus type 1 and survival of Myotis myotis bats in natural colonies. PLoS One 2:e566

> Anthony ELP, Kunz TH (1977) Feeding strategies of the little brown bat, Myotis lucifugus, in southern New Hampshire. Ecology 58:775-786

> Arlettaz R, Godat S, Meyer H (2000) Competition for food by expanding pipistrelle bat populations (Pipistrellus pipistrellus) might contribute to the decline of lesser horseshoe bats (Rhinolophus hipposideros). Biol Conserv 93: $55-60$

Arnett EB, Inkley DB, Johnson DH, Larkin RP and others (2007) Impacts of wind energy facilities on wildlife and wildlife habitat. Wildlife Society Technical Review 07-2. The Wildlife Society, Bethesda, MD

Arnett EB, Brown K, Erickson WP, Fielder J and others (2008) Patterns of fatality of bats at wind energy facilities in North America. J Wildl Manage 72:61-78

Avery MI (1985) Winter activity of pipistrelle bats. J Anim Ecol 54:721-728

Baerwald EF, D'Amours GH, Klug BJ, Barclay RMR (2008) Barotrauma is a significant cause of bat fatalities at wind turbines. Curr Biol 18:695-696

Bambini L, Blyth A, Bradford T, Bristol R and others (2006) Another Seychelles endemic close to extinction: the emballonurid bat Coleura seychellensis. Oryx 40:310-318

Barclay RMR (1991) Population structure of temperate zone bats in relation to foraging behaviour and energy demand. J Anim Ecol 60:165-178

Barclay RMR, Kurta A (2007) Ecology and behavior of bats roosting in tree cavities and under bark. In: Lacki ML, Hayes JP, Kurta A (eds) Bats in forests: conservation and management. Johns Hopkins University Press, Baltimore, MD, p 17-59

Bat Conservation Trust (2007) We'll weather the weather whatever the weather-but what about the bats? Bat News 84:4

Bengtsson J, Ahnström J, Weibull AC (2005) The effects of organic agriculture on biodiversity and abundance: a meta-analysis. J Appl Ecol 42:261-269 
Bharti AR, Nally JE, Ricaldi JN, Matthias MA and others (2003) Leptospirosis: a zoonotic disease of global importance. Lancet Infect Dis 3:757-771

Blehert DS, Hicks AC, Behr M, Meteyer CU and others (2009) Bat white-nose syndrome: an emerging fungal pathogen? Science 323:227

Boldogh S, Dobrosi D, Samu P (2007) The effects of the illumination of buildings on house-dwelling bats and its conservation consequences. Acta Chiropt 9:527-534

Bourne S, Hamilton-Smith E (2007) Miniopterus schreibersii bassanii and climate change. Australasian Bat Soc Newsl 28:67-69

Breed AC, Field HE, Epstein JH, Daszak P (2006) Emerging henipaviruses and flying foxes: conservation and management perspectives. Biol Conserv 131:211-220

Brinkman R (2006) Survey of possible operational impacts on bats by wind facilities in southern Germany. Report for Administrative District of Freiburg, Department 56, Conservation and Landscape Management. Ecological Consultancy, Gundelfingen

Brooke AP, Tschapka M (2002) Threats from overhunting to the flying fox, Pteropus tonganus, (Chiroptera: Pteropodidae) on Niue Island, South Pacific Ocean. Biol Conserv 103:343-348

Burns KF, Farinacci CJ, Murnane TG (1956) Insectivorous bats naturally infected with rabies in southwestern United States. Am J Public Health 46:1089-1097

Calisher $\mathrm{CH}$, Childs JE, Field HE, Holmes KV, Schountz T (2006) Bats: important reservoir hosts of emerging viruses. Clin Microbiol Rev 19:531-545

Calisher CH, Holmes KV, Dominguez SR, Schountz T, Cryan $P$ (2008) Bats prove to be rich reservoirs for emerging viruses. Microbe 3:521-528

Caro TM, O'Doherty G (1999) On the use of surrogate species in conservation biology. Conserv Biol 13:805-814

Carroll JB (1988) The conservation programme for the Rodrigues fruit bat Pteropus rodricensis. In: Dresser BL, Reese, RW, Maruska EJ (eds) Proceedings of the fifth world conference on breeding endangered species in captivity. Cincinnati Zoo and Botanical Gardens, Cincinnati, $\mathrm{OH}, \mathrm{p} 457-475$

Castro-Arellano I, Presley SJ, Saldanha LN, Willig MR, Wunderle JM Jr (2007) Effects of reduced impact logging on bat biodiversity in terra firme forest of lowland Amazonia. Biol Conserv 138:269-285

Chapin FS III, Zavaleta ES, Eviner VT, Naylor RL and others (2000) Consequences of changing biodiversity. Nature 405:234-242

Cheke AS, Dahl JF (1981) The status of bats on western Indian Ocean Islands with special reference to Pteropus. Mammalia 45:205-238

Clark DR Jr (1981) Bats and environmental contaminants: a review. US Fish and Wildlife Service Special Scientific Report, Wildlife No. 235, Washington, DC

Clark DR Jr (1988a) How sensitive are bats to insecticides? Wildl Soc Bull 16:399-403

Clark DR Jr (1988b) Environmental contaminants and the management of bat populations in the United States. In: Szaro RC, Severson KS, Patton DR (eds) Management of amphibians, reptiles, and small mammals in North America: proceedings of the symposium. US Department of Agriculture Forest Service, General Technical Report RM-166, Fort Collins, CO, p 409-413

$>$ Clark DR Jr (2001) DDT and the decline of free-tailed bats (Tadarida brasiliensis) at Carlsbad Cavern, New Mexico. Arch Environ Contam Toxicol 40:537-543

Clark DR Jr, Shore RF (2001) Chiroptera. In: Shore RF, Rattner
BA (eds) Ecotoxicology of wild mammals. John Wiley \& Sons, New York, p 159-214

Clark DR Jr, Kunz TH, Kaiser TE (1978a) Insecticides applied to a nursery colony of little brown bats (Myotis lucifugus): lethal concentrations in brain tissue. J Mammal 59:84-91

> Clark DR Jr, La Val RK, Swineford DM (1978b) Dieldrininduced mortality in an endangered species, the gray bat (Myotis grisescens). Science 199:1357-1359

Clarke FM, Pio DV, Racey PA (2005a) A comparison of logging systems and bat diversity in the neotropics. Conserv Biol 19:1194-1204

- Clarke FM, Rostant LV, Racey PA (2005b) Life after logging: post-logging recovery of a neotropical bat community. J Appl Ecol 42:409-420

Cleveland CJ, Frank JD, Federico P, Gomez I and others (2006) Economic value of the pest control service provided by Brazilian free-tailed bat in south-central Texas. Front Ecol Environ 4:238-243

Cody ML (1985) An introduction to habitat selection in birds. In: Cody ML (ed) Habitat selection in birds. Academic Press, Orlando, FL, p 4-56

Constantine DG (1967) Activity patterns of the Mexican freetailed bat. Univ N M Publ Biol 7:1-79

Craig P, Trail P, Morrell TE (1994) The decline of fruit bats in American Samoa due to hurricanes and overhunting. Biol Conserv 69:261-266

Cryan PM, Diehl R (2009) Analyzing bat migration. In: Kunz TH, Parsons S (eds) Ecological and behavioral methods for the study of bats, 2nd edn. Johns Hopkins University Press, Baltimore, MD, p 476-478

Cryan PM, Veilleux JP (2007) Migration and use of autumn, winter, and spring roosts by tree bats. In: Lacki MJ, Hayes JP, Kurta A (eds) Bats in forests: conservation and management. Johns Hopkins University Press, Baltimore, MD, p 153-176

Demma LJ, Schmitz A, Hanlon C, Rupprecht CE (2009) Public health concerns and bat researchers, with emphasis on rabies. In: Kunz TH, Parsons S (eds) Ecological and behavioral methods for the study of bats, 2nd edn. Johns Hopkins University Press, Baltimore, MD, p 828-849

Donald PF, Green RE, Heath MF (2001) Agricultural intensification and the collapse of Europe's farmland bird populations. Proc R Soc Ser B Biol Sci 268:25-29

Downs NC, Racey PA (2006) The use by bats of habitat features in mixed farmland in Scotland. Acta Chiropt 8: 169-185

Dunsmore JD, Hall LS, Kottek KH (1974) DDT in the bentwinged bat in Australia. Search 5:110-111

Estrada A, Coates-Estrada R (2001a) Bat species richness in live fences and in corridors of residual rain forest vegetation at Los Tuxtlas, Mexico. Ecography 24:94-102

> Estrada A, Coates-Estrada R (2001b) Species composition and reproductive phenology of bats in a tropical landscape at Los Tuxtlas, Mexico. J Trop Ecol 17:627-646

- Estrada A, Coates-Estrada R, Merrit D Jr (1993) Bat species richness and abundance in tropical rain forest fragments and in agricultural habitats at Los Tuxtlas, Mexico. Ecography 16:309-318

Ewers RM (2006) Interaction effects between economic development and forest cover determine deforestation rates. Glob Environ Change 16:161-169

Fahrig L (2003) Effects of habitat fragmentation on biodiversity. Annu Rev Ecol Evol Syst 34:487-515

> Federico P, Hallam TG, McCracken GF, Purucker ST and others (2008) Brazilian free-tailed bats (Tadarida brasiliensis) as insect predators in transgenic and conventional cotton crops. Ecol Appl 18:826-837 
Fenton MB, Acharya L, Audet D, Hickey MBC, Merriman C, Obrist MK, Syme DM (1992) Phyllostomid bats (Chiroptera: Phyllostomidae) as indicators of habitat disruption in the Neotropics. Biotropica 24:440-446

Fenton MB, Davison M, Kunz TH, McCracken GF, Racey PA, Tuttle MD, Dobson AP (2006) Linking bats to emerging diseases. Science 311:1098-1099

Flannery TF (1989) Flying foxes in Melanesia: populations at risk. Bats Mag 7:5-7

Flaquer C, Torre I, Arrizabalaga A (2007) Comparison of sampling methods for inventory of bat communities. J Mammal 88:526-533

Fleming TH, Racey PA (eds) (2009) Island bats. University of Chicago Press, Chicago, IL (in press)

Fleming TH, Valiente-Banuet A (eds) (2002) Columnar cacti and their mutualists: evolution, ecology, and conservation. University of Arizona Press, Tucson, AZ

Foley JA, DeFries R, Asner GP, Barford C and others (2005) Global consequences of land use. Science 309:570-574

Francis CM, Guillén A, Robinson MF (1999) Order Chiroptera: bats. In: Duckworth WJ, Salter RE, Khounboline K (eds) Wildlife in Lao PDR: 1999, status report. IUCN/WCS/Centre for Protected Areas and Watershed Management, Vientiane, Laos, p 225-235

Fujita MS, Tuttle MD (1991) Flying foxes (Chiroptera: Pteropodidae): threatened animals of key economic importance. Conserv Biol 5:455-463

Fukui D, Murakami M, Nakano S, Aoi T (2006) Effect of emergent aquatic insects on bat foraging in a riparian forest. J Anim Ecol 75:1252-1258

Fuller RJ, Gough SJ, Marchant JH (1995a) Bird populations in new lowland woods: landscape, design and management perspectives. In: Ferris-Kaan R (ed) The ecology of woodland creation. John Wiley \& Sons, London, p163-182

Fuller RJ, Gregory RD, Gibbons DW, Marchant JH, Wilson JH, Baillie JD, Carter SR (1995b) Population declines and range contractions among lowland farmland birds in Britain. Conserv Biol 9:1425-1441

Fuller RJ, Norton LR, Feber RE, Johnson PJ and others (2005) Benefits of organic farming to biodiversity vary among taxa. Biol Lett 1:431-434

Gannon MR, Willig MR (2009) Islands in the storm: disturbance ecology of plant-visiting bats in the hurricaneprone island of Puerto Rico. In: Fleming TH, Racey PA (eds) Island bats. University of Chicago Press, Chicago IL (in press)

Gardner AL (1977) Feeding habits. In: Baker RJ, Jones JK Jr, Carter DC (eds) Biology of bats of the New World family Phyllostomatidae, Part II. Spec Publ Mus Texas Tech University, Lubbock, TX, no. 13, p 293-350

Gardner TA, Barlow J, Araujo IS, Ávila-Pires TC and others (2008) The cost-effectiveness of biodiversity surveys in tropical forests. Ecol Lett 11:139-150

Geluso KN, Altenbach JS, Wilson DE (1976) Bat mortality: pesticide poisoning and migratory stress. Science 194: 184-186

Geluso KN, Altenbach JS, Wilson DE (1979) Population size of Tadarida brasiliensis at Carlsbad Caverns in 1973. In Genoways HH, Baker RJ (eds) Biological investigations in the Guadalupe Mountains National Park, Texas. Proceedings and Transactions Series no. 4, US National Park Service, Washington, DC, p 341-348

> Geluso KN, Altenbach JS, Wilson DE (1981) Organochlorine residues in young Mexican free-tailed bats from several roosts. Am Midl Nat 105:249-257

Gorresen PM, Willig MR (2004) Landscape responses of bats to habitat fragmentation in the Atlantic forest of Paraguay. J Mammal 85:688-697
Gregory RD, van Strein A, Vorisek P, Gmelig Meyling AM, Noble DG, Foppen RPB, Gibbons DW (2005) Developing indicators for European birds. Proc R Soc Ser B Biol Sci 360:269-288

Griffin DR, Webster FA, Michael CR (1960) The echolocation of flying insects by bats. Anim Behav 8:141-154

Halstead LB (1977) Fruit bats: an example of wildlife management. Nigerian Field 42:50-56

Harris SL, Brooks SM, Jones G, Hutson AM and others (2006) European bay lyssaviruses: distribution, prevalence and implications for conservation. Biol Conserv 131:193-210

Hayes JP, Loeb SC (2007) The influences of forest management on bats in North America. In: Lacki ML, Hayes JP, Kurta A (eds) Bats in forests: conservation and management. Johns Hopkins University Press, Baltimore, MD, p 207-235

Hayes JP, Ober HK, Sherwin RE (2009) Survey and monitoring of bats. In: Kunz TH, Parsons S (eds) Ecological and behavioral methods for the study of bats, 2nd edn. Johns Hopkins University Press, Baltimore, MD, p 115-132

> Henry M, Cosson JF, Pons JM (2007) Abundance may be a misleading indicator of fragmentation-sensitivity: the case of fig-eating bats. Biol Conserv 139:462-467

- Hernández LM, Ibáñez MA, Fernández A, Guillén AM, González J, Pérez JL (1993) Organochlorine insecticide and PCB residues in two bat species from four localities in Spain. Bull Environ Contam Toxicol 50:871-877

Hill CJ (1996) Habitat specificity and food preferences of an assemblage of tropical Australian dung beetles. J Trop Ecol 12:449-460

- Hirano M (1989) Characteristics of pyrethroids for insect pest control in agriculture. J Pestic Sci 27:353-360

Hodgkison R, Balding ST, Zubaid A, Kunz TH (2003) Fruit bats (Chiroptera: Pteropodidae) as seed dispersers and pollinators in a lowland Malaysian rain forest. Biotropica 35:491-502

> Hole DG, Perkins AJ, Wilson JD, Alexander IH, Grice PV, Evans AD (2005) Does organic farming benefit biodiversity? Biol Conserv 122:113-130

$>$ Hooper DU, Chapin FS, Ewel JJ, Hector A and others (2005) Effects of biodiversity on ecosystem functioning: a consensus of current knowledge. Ecol Monogr 75:3-35

- Hughes L (2000) Biological consequences of global warming: Is the signal already apparent? Trends Ecol Evol 15:56-61

- Humphries MM, Thomas DW, Speakman JR (2002) Climatemediated energetic constraints on the distribution of hibernating mammals. Nature 418:313-316

Hutson AM, Mickleburgh SP, Racey PA (eds) (2001) Global action plan for microchiropteran bats. IUCN, Gland

Ibáñez C (1997) Winter reproduction in the greater mouseeared bat (Myotis myotis) in South Iberia. J Zool 243: 836-840

Jacobs DS, Eick GN, Schoeman MC, Matthee CA (2006) Cryptic species in an insectivorous bat Scotophilus dinganii. J Mammal 87:161-170

Jefferies DJ (1972) Organochlorine insecticide residues in British bats and their significance. J Zool 166:245-263

Jenkins RKB, Racey PA (2008) Bats as bushmeat in Madagascar. Madag Conserv Dev 3:22-30

Jones G, Van Parijs SM (1993) Bimodal echolocation in pipistrelle bats: Are cryptic species present? Proc R Soc Ser B Biol Sci 251:119-125

Kalcounis-Rueppell MC, Payne VH, Huff SR, Boyko AL (2007) Effects of wastewater treatment plant effluent on bat foraging activity in an urban stream system. Biol Conserv 138:120-130 
Kalka MB, Smith AR, Kalko EKV (2008) Bats limit arthropods and herbivory in a tropical forest. Science 320:71

Kalko EKV (1998) Organisation and diversity of tropical bat communities through space and time. Zool Anal Complex Syst 101:281-297

Kalko EKV, Handley CO Jr (2001) Neotropical bats in the canopy: diversity, community structure, and implications for conservation. Plant Ecol 153:319-333

Kalko EKV, Handley CO Jr, Handley D (1996) Organization, diversity and long-term dynamics of a neotropical community. In: Cody ML, Smallwood JA (eds) Long-term studies of vertebrate communities. Academic Press, San Diego, CA, p 503-553

Kareiva P, Watts S, McDonald R, Boucher T (2007) Domesticated nature: shaping landscapes and ecosystems for human welfare. Science 316:1866-1869

Kearney C, Volleth M, Contrafatto G, Taylor PJ (2002) Systematic implications of chromosome GTG-band and bacula morphology for southern African Eptesicus and Pipistrellus and several other species of Vespertilioninae (Chiroptera: Vespertilionidae). Acta Chiropt 4: $55-76$

Keeley BK, Tuttle MD (1999) Bats in American bridges. Bat Conservation International, Resource Publication no. 4, Austin, TX

Kelm DH, Wiesner K, von Helversen O (2008) Effects of artificial roosts for frugivorous bats on seed dispersal in a neotropical forest pasture mosaic. Conserv Biol 22: 733-741

Kiefer A, Mayer F, Kosuch J, von Helversen O, Veith M (2002) Conflicting molecular phylogenies of European longeared bats (Plecotus) can be explained by cryptic diversity. Mol Phylogenet Evol 25:557-566

King AA, Meredith CD, Thompson GR (1994) The biology of southern African lyssavirus variants. Curr Top Microbiol Immunol 187:267-295

Kingston T, Rossiter SJ (2004) Harmonic-hopping in Wallacea's bats. Nature 429:654-657

Kingston T, Lara M, Jones G, Schneider C, Zubaid A, Kunz TH (2001) Acoustic divergence in two cryptic Hipposideros species: a role for sexual selection. Proc R Soc Ser B Biol Sci 268:1381-1386

Klingbeil BT, Willig MR (2009) Multi-scale responses of frugivorous and gleaning animalivorous bats to landscape composition and configuration in fragmented landscapes of lowland Amazonia. J Appl Ecol 46:203-213

Kokurewicz T (1995) Increased population of Daubenton's bat (Myotis daubentonii, Kuhl 1819) (Chiroptera, Vespertilionidae) in Poland. Myotis 32-33:155-161

Koskimies P (1989) Birds as a tool in environmental monitoring. Ann Zool Fenn 26:153-166

Kunz TH (1982) Roosting ecology of bats. In: Kunz TH (ed) Ecology of bats. Plenum Press, New York, p 1-55

Kunz TH (1996) Obligate and opportunistic interactions of Old World tropical bats and plants. In: Hasan ZA, Zubaid A (eds) Conservation and faunal biodiversity in Malaysia. Penerbit Universiti Kebangsaan Malaysia, Kuala Lumpur, p 37-65

Kunz TH (2003) Censusing bats: challenges, solutions, and sampling biases. In: O'Shea TJ, Bogan MA (eds) Monitoring trends in bat populations of the United States and territories: problems and prospects. US Geological Survey, Biological Resources Division, Information and Technology Report, USGS/BRD/ITR-2003-003, Washington, DC, p 9-20

Kunz TH, Fenton MB (2003) Bat ecology. University of Chicago Press, Chicago, IL
Kunz TH, Lumsden LF (2003) Ecology of cavity and foliage roosting bats. In: Kunz TH, Fenton MB (eds) Bat ecology. University of Chicago Press, Chicago, IL, p 3-89

Kunz TH, Parsons S (eds) (2009) Ecological and behavioral methods for the study of bats. Johns Hopkins University Press, Baltimore, MD

Kunz TH, Pierson ED (1994) Bats of the world: an introduction. In: Nowak RW (ed) Walker's bats of the world. Johns Hopkins University Press, Baltimore, MD, p 1-46

Kunz TH, Reynolds DS (2003) Bat colonies in buildings. In: O'Shea TJ, Bogan MA (eds) Monitoring trends in bat populations of the United States and territories: problems and prospects. US Geological Survey, Biological Resources Division, Information and Technology Report, USGS/ BRD/ITR-2003-003, Washington, DC, p 91-102

$>$ Kunz TH, Anthony ELP, Rumage WT (1977) Mortality of little brown bats following multiple pesticide applications. J Wildl Manage 41:476-483

Kunz TH, Arnett EB, Erickson WP, Johnson GD and others (2007) Ecological impacts of wind energy development on bats: questions, hypotheses, and research needs. Front Ecol Environ 5:315-324

Kunz TH, Gauthreaux SA Jr, Hristov NI, Horn JW and others (2008) Aeroecology: probing and modeling the aerosphere. Integr Comp Biol 48:1-11

Kunz TH, Betke M, Hristov NI, Vonhof M (2009a) Methods for assessing colony size, population size, and relative abundance of bats. In: Kunz TH, Parsons S (eds) Ecological and behavioral methods for the study of bats, 2nd edn. Johns Hopkins University Press, Baltimore, MD (in press)

Kunz TH, Hodkison R, Weise C (2009b) Methods of capturing and handling bats. In: Kunz $\mathrm{TH}$, Parsons $\mathrm{S}$ (eds) Ecological and behavioral methods for the study of bats, 2nd edn. Johns Hopkins University Press, Baltimore, MD (in press)

Kurta A, Bell GP, Nagy KA, Kunz TH (1989) Energetics of pregnancy and lactation in free-ranging little brown bats (Myotis lucifugus). Physiol Zool 62:808-818

Kushlan JM (1993) Colonial waterbirds as bioindicators of environmental change. Colon Waterbirds 16:223-25

Lacki MJ, Hayes JP, Kurta A (2007) Bats in forests. Johns Hopkins University Press, Baltimore, MD

LaDeau SL, Kilpatrick AM, Marra PP (2007) West Nile virus emergence and large-scale declines of North American bird populations. Nature 447:710-713

- Landres PB, Verner J, Thomas JW (1988) Ecological uses of vertebrate indicator species: a critique. Conserv Biol 2: 316-327

Lau SKP, Woo PCY, Li KSM, Huang Y and others (2005) Severe acute respiratory syndrome coronavirus-like virus in Chinese horseshoe bats. Proc Natl Acad Sci USA 102: 14040-14045

LaVal RK (2004) Impact of global warming and locally changing climate on tropical cloud forest bats. J Mammal 85: $237-244$

Lee YF, McCracken GF (2005) Dietary variation of Brazilian free-tailed bats links to migratory populations of pest insects. J Mammal 86:67-96

Lehlé C, Razafitrimo G, Razainirina J, Andriaholinirina N and others (2007) Henipavirus and Tioman virus antibodies in pteropodid bats, Madagascar. Emerg Infect Dis 13: 159-161

- Leroy EM, Kumulungui B, Pourrut X, Rouquet P and others (2005) Fruit bats as reservoirs of Ebola virus. Nature 438:575-576

Levin SA (1992) The problem of pattern and scale in ecology. Ecology 73:1943-1967 
Lewis T, Dibley GC (1970) Air movement near windbreaks and a hypothesis of the mechanism of the accumulation of airborne insects. Ann Appl Biol 66:477-484

Li W, Shi Z, Yu M, Ren W and others (2005) Bats are natural reservoirs of SARS-like coronaviruses. Science 310: 676-679

Locke R (2008) Mysterious bat die-off triggers alarm. Bats 26(1):13-14

Louette M, Bijnens L, Upoki Agenong'a D, Fotso RC (1995) The utility of birds as bioindicators: case-studies in Equatorial Africa. Belg J Zool 125:157-165

MacSwiney MC, Clarke FM, Racey PA (2008) What you see is not what you get: the role of ultrasonic detectors in increasing inventory completeness in neotropical bat assemblages. J Appl Ecol 45:1364-1371

Maki S, Kalliola R, Vuorinen K (2001) Road construction in the Peruvian Amazon: causes and consequences. Environ Conserv 28:199-214

Mason CF (1997) Biology of freshwater pollution, 3rd edn. Longman, Harlow

Matthias MA, Díaz M, Campos KJ, Calderon M and others (2005) Diversity of bat-associated Leptospira in the Peruvian Amazon inferred by Bayesian phylogenetic analysis of $16 \mathrm{~S}$ ribosomal DNA sequences. Am J Trop Med Hyg 73:964-974

Mayer F, von Helversen O (2001) Cryptic diversity in European bats. Proc R Soc Ser B Biol Sci 268:1825-1832

McCarty JP (2001) Review: ecological consequences of recent climate change. Conserv Biol 15:320-331

McGeoch MA (1998) The selection, testing and application of terrestrial insects as bioindicators. Biol Rev Camb Philos Soc 73:181-201

McGeoch MA (2007) Insects and bioindication: theory and progress. In: Stewart AJA, New TR, Lewis OT (eds) Insect conservation biology. CABI Publishing, London, $p$ 144-174

McGeoch M, Van Rensburg BJ, Botes A (2002) The verification and application of bioindicators: a case study of dung beetles in a savanna ecosystem. J Appl Ecol 39:661-672

McWilliam AN (1982) Adaptive responses to seasonality in four species of Microchiroptera in coastal Kenya. PhD thesis, University of Aberdeen

McWilliam AN (1994) Nocturnal animals. In: Douthwaite TJR, Tingle CCD (eds) DDT in the tropics: the impact on wildlife in Zimbabwe of ground-spraying for tsetse-fly control. Natural Resources Institute, Chatham, p 103-133

Medellín R, Equihua M, Amín MA (2000) Bat diversity and abundance as indicators of disturbance in Neotropical rainforests. Conserv Biol 14:1666-1675

Messenger SL, Rupprecht CE, Smith JS (2003) Bats, emerging virus infections, and the rabies paradigm. In: Kunz $\mathrm{TH}$, Fenton MB (eds) Bat ecology. University of Chicago Press, Chicago, IL, p 676-679

Mickleburgh S, Waylen K, Racey PA (2009) Bats as bushmeat: a global review. Oryx (in press)

Molina-Freaner F, Rojas-Martínez A, Fleming TH, ValienteBanuet A (2004) Pollination biology of the columnar cactus Pachycereus pectin-aboriginum in north-western México. J Arid Environ 56:117-127

Moreno CE, Halffter G (2000) Assessing the completeness of bat biodiversity using species accumulation curves. J Appl Ecol 37:149-158

Moreno CE, Halffter G (2001) Spatial and temporal analysis of $\alpha, \beta$ and $\gamma$ diversities of bats in a fragmented landscape. Biodivers Conserv 10:367-382

> Moreno CE, Sánchez-Rojas G, Pineda E, Escobar F (2007) Shortcuts for biodiversity evaluation: a review of terminol- ogy and recommendations for the use of target groups, bioindicators and surrogates. Int J Environ Health 1:71-86

$>$ Newson SE, Mendes S, Crick HQP, Dulvy NK and others (2009) Indicators of the impact of climate change on migratory species. Endang Species Res 7:101-113

Niemela J, Haila Y, Puntilla P (1996) The importance of small scale heterogeneity in boreal forests: variation in diversity in forest-floor invertebrates across the succession gradient. Ecography 199:352-368

NRC (National Research Council) (2001) Grand challenges in environmental sciences. National Academy Press, Washington, DC

NRC (National Research Council) (2003) NEON: addressing the nation's environmental challenges. National Academy Press, Washington, DC

NRC (National Research Council) (2007) Environmental impacts of wind-energy projects. National Academy Press, Washington, DC

O'Shea TJ, Bogan MA (eds) (2003) Monitoring trends in bat populations of the United States and territories: problems and prospects. US Geological Survey, Biological Resources Division, Information and Technology Report, USGS/BRD/ITR-2003-003, Washington, DC

O'Shea TJ, Clark DR Jr (2002) An overview of contaminants and bats, with special reference to insecticides and the Indiana bat. In: Kurta, A, Kennedy J (eds) The Indiana bat: biology and management of an endangered species. Bat Conservation International, Austin, TX, p 237-253

O'Shea TJ, Johnson JJ (2009) Environmental contaminants and bats: investigating exposure and effects. In: Kunz TH, Parsons S (eds) Ecological and behavioral methods for the study of bats, 2nd edn. Johns Hopkins University Press, Baltimore, MD, p 500-528

Ormsbee PC, Kiser JD, Perlmeter SI (2007) Importance of night roosts to the ecology of bats. In: Lacki ML, Hayes JP, Kurta A (eds) Bats in forests: conservation and management. Johns Hopkins University Press, Baltimore, MD, p 129-151

> Park KJ, Cristinacce A (2006) The use of sewage treatment works as foraging sites by insectivorous bats. Anim Conserv 9:259-268

Parmesan C (2006) Ecological and evolutionary responses to recent climate change. Annu Rev Ecol Evol Syst 37: 637-669

Parmesan C, Yohe G (2003) A globally coherent fingerprint of climate change impacts across natural systems. Nature 421:37-42

Parsons S, Szewczak JM (2009) Detecting, recording, and analyzing the vocalizations of bats. In: Kunz TH, Parsons S (eds) Ecological and behavioral methods for the study of bats, 2nd edn. Johns Hopkins University Press, Baltimore, MD, p 91-112

Patterson BD, Willig MR, Stevens RD (2003) Trophic strategies, niche partitioning, and patterns of ecological organization. In: Kunz TH, Fenton MB (eds) Bat ecology. University of Chicago Press, Chicago, IL, p 536-579

Pearson DL, Cassola F (1992) World-wide species richness patterns of tiger beetles (Coleoptera: Cicindelidae): indicator taxon for biodiversity and conservation studies. Conserv Biol 6:376-391

Pedersen SC, Kwiecinski GG, Larsen PA, Genoways HG, Morton MN (2009) Fruit bats of Montserrat: population fluctuation in response to hurricanes and volcanoes over a 25 year period 1979-2004. In: Fleming TH, Racey PA (eds) Island bats. University of Chicago Press, Chicago, IL (in press)

Peterle JJ (1991) Wildlife toxicology. Van Nostrand Reinhold, New York 
Peterson TC, Zhang X, Brunet-India M, Vázquez-Aguirre JL (2008) Changes in North American extremes derived from daily weather data. J Geophys Res 113:D07113. doi: 10.1029/2007JD009453

Pierson ED (1998) Tall trees, deep holes, and scarred landscapes: conservation biology of North American bats. In: Kunz TH, Racey PA (eds). Bat biology and conservation. University of Chicago Press, Chicago, IL, p 309-325

Pierson ED, Rainey WE (1992) The biology of flying foxes of the genus Pteropus: a review. In: Wilson DE, Graham GL (eds) Pacific island flying foxes: proceedings of an international conservation conference. Biological Report 90(23), US Fish and Wildlife Service, Washington, DC, p 1-17

Pierson ED, Elmqvist ST, Rainey WE, Cox PA (1996) Effects of tropical cyclonic storms on flying fox populations on the South Pacific Islands of Samoa. Conserv Biol 10:438-451

Pimm SL, Russell GJ, Gittleman JL, Brooks TM (1995) The future of biodiversity. Science 269:347-350

Pineda E, Moreno CE, Escobar F, Halffter G (2005) Frog, bat and dung beetle diversity in the cloud forest and coffee agroecosystems of Veracruz, Mexico. Conserv Biol 19: 400-410

Pocock MJO, Jennings N (2008) Testing biotic indicator taxa: the sensitivity of insectivorous mammals and their prey to the intensification of lowland agriculture. J Appl Ecol 45: 151-160

Presley SJ, Willig MR, Wunderle JM Jr, Saldanha LN (2008) Effects of reduced-impact logging and forest physiognomy on bat populations of lowland Amazonian forest. J Appl Ecol 45:14-25

Presley SJ, Willig MR, Castro-Arellano I, Weaver SC (2009) Effects of habitat conversion on temporal activity patterns of phyllostomid bats in lowland Amazonian rainforest. J Mammal 90:210-221

Racey PA (1972) Aspects of reproduction in some heterothermic bats. PhD thesis, University of London.

Racey PA (1973) Environmental factors affecting the length of gestation in heterothermic bats. J Reprod Fertil 19 (Suppl):175-189

Racey PA (1982) Ecology of reproduction. In: Kunz TH (ed) Ecology of bats. Plenum Press, New York, p 57-104

Racey PA (2000) Does legislation conserve and does research drive policy? The case of bats in the UK. In: Entwistle AC, Dunstone N (eds) Priorities for the conservation of mammalian biodiversity. Has the panda had its day? Cambridge University Press, Cambridge, p 159-175

Racey PA, Entwistle AC (2000) Life-history and reproductive strategies of bats. In: Crichton EG, Krutzsch PH (eds) Reproductive biology of bats. Academic Press, London, p 363-414

Racey PA, Swift SM (1981) Variations in gestation length in a colony of pipistrelle bats (Pipistrellus pipistrellus) from year to year. J Reprod Fertil 61:123-129

Racey PA, Swift SM (1986) Residual effects of remedial timber treatments on bats. Biol Conserv 35:205-214

Racey PA, Swift SM, Rydell J, Brodie L (1998) Bats and insects over two Scottish rivers with contrasting nitrate status. Anim Conserv 1:195-202

Racey PA, Goodman SM, Jenkins RKB (2009) The ecology and conservation of Malagasy bats. In: Fleming TH, Racey PA (eds) Island bats. University of Chicago Press, Chicago, IL (in press)

Rainey WE (1998) Conservation of bats on remote IndoPacific islands. In: Kunz, TH, Racey PA (eds) Bat biology and conservation. Smithsonian Institution Press, Washington, DC, p 326-341

Ransome RD, McOwat TP (1994) Birth timing and population changes in greater horseshoe bat colonies (Rhinolophus ferrumequinum) are synchronized by climatic temperature. Zool J Linn Soc 112:337-351

Rex K, Kelm DH, Wiesner K, Matt FG, Kunz TH, Voigt CC (2008) Species richness and structure of three phyllostomid bat assemblages. Biol J Linn Soc 94:617-629

Reynaud PA, Thioulouse J (2000) Identification of birds as biological markers along a neotropical urban-rural gradient (Cayenne, French Guiana), using co-inertia analysis. J Environ Manage 59:121-140

Robinson RA, Sutherland WJ (2002) Post-war changes in arable farming and biodiversity in Great Britain. J Appl Ecol 39:157-176

Rosenzweig C, Casassa G, Karoly DJ, Imeson A and others (2007) Assessment of observed changes and responses in natural and managed systems. In: Parry ML, Canziani OF, Palutikof JP, van der Linden PJ, Hanson CE (eds) Climate change 2007: impacts, adaptation and vulnerability. Contribution of Working Group II to the 4th assessment report of the Intergovernmental Panel on Climate Change. Cambridge University Press, Cambridge, p 79-131

Roue SY, Nemoz M (2004) Unusual mortality in Schreiber's long fingered bat, at several nurseries. Wildl Dis Assoc Newsl 14:4

> Russell AL, Butchkoski CM, Saidak L, McCracken GF (2009) Road-killed bats, highway design, and commuting ecology of bats. Endang Species Res 8:49-60

Russo D (2002) Elevation affects the distribution of the two sexes in Daubenton's bats Myotis daubentonii (Chiroptera: Vespertilionidae) from Italy. Mammalia 66: $543-551$

Rydell J (1992) Exploitation of insects around streetlamps by bats in Sweden. Funct Ecol 6:744-750

Sachanowicz K, Wower A, Bashta AT (2006) Further range extension of Pipistrellus kuhlii (Kuhl, 1817) in central and eastern Europe. Acta Chiropt 8:543-548

Sala OE, Chapin FS III, Armesto JJ, Berlow E and others (2000) Global biodiversity scenarios for the year 2100. Science 287:1770-1774

Schaub A, Ostwald J, Siemers BM (2008) Foraging bats avoid noise. J Exp Biol 211:3174-3180

Schulze MD, Seavy NE, Whitacre DF (2000) A comparison of the phyllostomid bat assemblages in undisturbed neotropical forest and in forest fragments of a slash-and-burn farming mosaic in Petén, Guatemala. Biotropica 32: $174-184$

Senior P, Butlin RK, Altringham JD (2005) Sex and segregation in temperate bats. Proc R Soc Ser B Biol Sci 272: $2467-2473$

Simmons NB (2005) Order Chiroptera. In: Wilson DE, Reeder DM (eds) Mammal species of the world, Vol 1, 3rd edn. Johns Hopkins University Press, Baltimore, MD, p 312-529

Simmons NB, Conway TM (2003) Evolution of ecological diversity. In: Kunz TH, Fenton MB (eds) Bat ecology. University of Chicago Press, Chicago, IL, p 493-535

Skerratt LF, Speare R, Berger L, Winsor H (1998) Lyssaviral infection and lead poisoning in black flying foxes from Queensland. J Wildl Dis 34:355-361

Soares-Filho BS, Nepstad DC, Cuarran LM, Cerqueira GC and others (2006) Modelling conservation in the Amazon basin. Nature 440:520-523

Spector S, Forsyth AD (1998) Indicator taxa for biodiversity assessment in the vanishing tropics. In: Mace G, Balmford A, Ginsberg JR (eds) Conservation in a changing world. Cambridge University Press, Cambridge, p 181-209

Start AN, Marshall AG (1976) Nectarivorous bats as pollinators of trees in West Malaysia. In: Burley J, Styles BT (eds) 
Tropical trees: variation, breeding and conservation. Academic Press, London, p 141-50

Stebbings RE (1988) Conservation of European bats. Christopher Helm, London

Stevens RD, Willig MR (2002) Geographical ecology at the community level: perspectives on the diversity of New World bats. Ecology 83:545-560

Stevens RD, Cox SB, Strauss RD, Willig MR (2003) Broadscale patterns in functional diversity across an extensive environmental gradient: vertebrate consumers, hidden treatments and latitudinal trends. Ecol Lett 6:1099-1108

Stevens RD, Willig MR, Strauss RE (2006) Latitudinal gradients in the phenetic diversity of New World bat communities. Oikos 112:41-50

Sutton RH, Wilson PD (1983) Lead poisoning in grey-headed fruit bats (Pteropus poliocephalus). J Wildl Dis 19:294-296

Swanepoel RE, Racey PA, Shore RF, Speakman JR (1999) Energetic effects of sub-lethal exposure to lindane on pipistrelle bats (Pipistrellus pipistrellus). Environ Pollut 104:169-177

Thomas CD, Cameron A, Green RE, Bakkenes M and others (2004) Extinction risk from climate change. Nature 427:145-148

Tilman D, Fargione J, Wolff B, D'Antonio C and others (2001) Forecasting agriculturally driven global environmental change. Science 292:281-284

Turner MG, Gardner RH, O'Neill RV (2001) Landscape ecology in theory and practice: pattern and process. SpringerVerlag, New York

Tuttle MD, Hensley D (1993) Bat houses: the secret of success. Bats 11(1):3-14

van Horne B (1983) Density as a misleading indicator of habitat quality. J Wildl Manag 47:893-901

> Vaughan N, Jones G, Harris S (1996) Effects of sewage effluent on the activity of bats (Chiroptera: Vespertilionidae) foraging along rivers. Biol Conserv 78:337-343

Verboom B, Huitema H (1997) The importance of linear landscape elements for the pipistrelle Pipistrellus pipistrellus and the serotine bat Eptesicus serotinus. Landscape Ecol 12:117-125

Vitousek PM, Mooney HA, Lubchenco J, Melillo JM (1997) Human domination of Earth's ecosystems. Science 277:494-499

Voûte AM (1981) The conflict between bats and wood preservatives. Myotis 19:41-44

Walsh A, Catto C, Hutson AM, Racey PA, Richardson PW Langton S (2001) The UK's National Bat Monitoring Programme. Final Report 2001. DETR Contract No. CR018. Crown Copyright, HMSO, Norwich

Walther GR, Post E, Convey P, Menzel A and others (2002) Ecological responses to recent climate change. Nature 416:389-395

Welbergen JA, Klose SM, Markus N, Eby P (2008) Climate change and the effects of temperature extremes in Australian flying foxes. Proc R Soc Ser B Biol Sci 275:419-425

Whitaker JO Jr (1993) Bats, beetles, and bugs. Bats 11(1):23

Editorial responsibility: Stephen Rossiter, London, UK
Whitaker JO Jr (1995) Food of the big brown bat, Eptesicus fuscus, from maternity colonies in Indiana and Illinois. Am Midl Nat 134:346-360

- Whitehurst IT, Lindsey BI (1990) The impact of organic enrichment on the benthic macroinvertebrate communities of a lowland river. Water Res 24:625-630

> Wibbelt G, Kurth A, Yasmum N, Bannert M, Nagel S, Nitsche A, Ehlers B (2007) Discovery of herpesviruses in bats. J Gen Virol 88:2651-2655

Wickramasinghe LP, Harris S, Jones G, Vaughan N (2003) Bat activity and species richness on organic and conventional farms: impact of agricultural intensification. J Appl Ecol 40:984-993

- Wickramasinghe LP, Harris S, Jones G, Jennings NV (2004) Abundance and species richness of nocturnal insects on organic and conventional farms: effects of agricultural intensification on bat foraging. Conserv Biol 18:1283-1292

> Wilcox BA, Murphy DD (1985) Conservation strategy: the effects of fragmentation on extinction. Am Nat 125: 879-887

Wiles GJ (1992) Recent trends in the fruit bat trade in Guam. In: Wilson DE, Graham GL (eds) Pacific island flying foxes: proceedings of an international conservation conference. Biological Report 90(23), US Fish and Wildlife Service, Washington, DC, p 53-60

Wiles GJ, Brooke A (2009) Conservation threats to bats in the Pacific islands and insular Southeast Asia. In Fleming TH, Racey PA (eds) Island bats. University of Chicago Press, Chicago, IL (in press)

Wiles GJ, Engbring J, Otobed D (1997) Abundance, biology and human exploitation of bats in the Palau Islands. J Zool 241:203-227

Williams-Guillén K, Perfecto I, Vandermeer J (2008) Bats limit insects in a Neotropical agroforestry ecosystem. Science 320:70

Willig MR, Sandlin EA (1991) Gradients of species density and turnover in New World bats: a comparison of quadrat and band methodologies. In: Mares MA, Schmidly DJ (eds) Latin American mammalogy: history, biodiversity, and conservation. University of Oklahoma Press, OK, p 81-96

Willig MR, Selcer KW (1989) Bat species density gradients in the New World: a statistical assessment. J Biogeogr 16: 189-195

Willig MR, Patterson BD, Stevens RD (2003) Patterns of range size, richness, and body size in the Chiroptera. In: Kunz TH, Fenton MB (eds) Bat ecology. University of Chicago Press, Chicago, IL, p 580-621

Willig MR, Presley SJ, Bloch CP, Hice CL and others (2007) Phyllostomid bats of lowland Amazonia: effects of habitat alteration on abundance. Biotropica 39:737-746

> With KA, Crist TO (1995) Critical thresholds in species' responses to landscape structure. Ecology 76:2446-2459

Zook BC, Sauer RM, Garner FM (1970) Lead poisoning in Australian fruit bats (Pteropus poliocephalus). J Am Vet Med Assoc 157:691-694

Submitted: July 29, 2008; Accepted: January 6, 2009

Proofs received from author(s): April 3, 2009 